\title{
Stem Cells Use Distinct Self-renewal Programs at Different Ages
}

\author{
B.P. LEVI AND S.J. MORRISON \\ Howard Hughes Medical Institute, Department of Internal Medicine, and Center for Stem Cell Biology, \\ Life Sciences Institute, University of Michigan, Ann Arbor, Michigan 48109-2216
}

\begin{abstract}
Stem cells expand in number during development and persist throughout life by undergoing self-renewing divisions. The question of how stem cells self-renew throughout life is a fundamental problem in cell biology, with broad implications for understanding development, tissue regeneration, cancer, and aging. Recent insights demonstrate that self-renewal programs depend on key transcriptional regulators that are often shared among stem cells in different tissues but that often change between stem cells at different stages of life: Embryonic, fetal, young adult, and old adult stem cells are maintained by different self-renewal programs. Self-renewal programs change over time to contend with changes in tissue growth and repair demands as well as the increasing risk of malignant transformation during aging. The downstream mechanisms by which these programs regulate the cell cycle, developmental potential, and timing of differentiation are just starting to be elucidated. One key requirement for self-renewal is repression of the $\mathrm{p} 16^{\text {Ink4a }}$ and $\mathrm{p} 19^{\text {Arf }}$ tumor suppressors. This is accomplished by overlapping transcriptional regulators whose expression and function change with age, so as to maintain self-renewal potential throughout life while allowing increased expression of $\mathrm{p} 16^{\text {Ink4a }}$ and $\mathrm{p} 19^{\text {Arf }}$ in aging stem cells. This reduces stem cell function in aging tissues but also reduces cancer incidence.
\end{abstract}

Stem cells maintain themselves throughout life by undergoing self-renewing divisions in which a mother stem cell gives rise to one or two daughter stem cells that have a developmental potential indistinguishable from that of the mother cell (Molofsky et al. 2004). In the hematopoietic system, stem cell self-renewal can be measured in vivo by the ability of single hematopoietic stem cells (HSCs) to give long-term multilineage reconstitution of irradiated mice and for the progeny of these cells to give long-term multilineage reconstitution of multiple secondary recipients. Individual HSCs have extensive self-renewal capacity (Harrison and Astle 1982; Morrison et al. 1997), although this capacity declines with age (Chen et al. 2000; Janzen et al. 2006). In the nervous system, self-renewal is measured by subcloning multilineage colonies that arise from single stem cells to determine the number of multipotent daughter cells that are formed by individual multipotent mother cells (Bixby et al. 2002; Kruger et al. 2002; Molofsky et al. 2003, 2005, 2006). As in the hematopoietic system, neural stem cells can selfrenew extensively, but this self-renewal potential declines with age (Kruger et al. 2002; Molofsky et al. 2006). Many of the same genes are required for hematopoietic and neural stem cell self-renewal, demonstrating that although self-renewal is measured differently in the two systems, both assays reflect the function of a core program of selfrenewal regulators that is often shared between tissues.

Stem cells change their properties and their regulation over time, consistent with the changing demands of tissue growth. Stem cell numbers must expand rapidly during development to support tissue formation and growth. Both HSCs and neural stem cells are thought to undergo rapid, symmetric self-renewing divisions to enable this expansion during fetal development (Chenn and McConnell 1995; Morrison et al. 1995; Noctor et al. 2004). However, as tissue growth slows postnatally, stem cell division also slows, and a higher proportion of the divisions are likely to be asymmetric (for review, see Morrison and Kimble 2006). Throughout adulthood, stem cells in many tissues appear to be quiescent most of the time but regularly enter cycle to maintain tissue homeostasis (Morrison and Kimble 2006). Self-renewal programs must therefore change between the fetal, neonatal, and young adult stages to accommodate developmental changes in the frequency and symmetry of stem cell division (Table 1).

Additional changes occur in stem cells between young adulthood and old adulthood as stem cells struggle to maintain homeostasis within aging tissues and to avoid neoplastic transformation. Genetic mutations (Rossi et al. 2007) and damage from reactive oxygen species (Ito et al. 2006) accumulate with age in stem cells, impairing stem cell function and increasing the risk of neoplastic transformation. There are also changes during aging in the rate at which stem cells divide, the fates they are likely to acquire, their frequency, and their self-renewal potential (Kuhn et al. 1996; Morrison et al. 1996; de Haan et al. 1997; de Haan and Van Zant 1999; Enwere et al. 2004; Rossi et al. 2005; Janzen et al. 2006; Molofsky et al. 2006). The overall effect of these changes is to reduce stem cell function and regenerative capacity in aging tissues. These changes likely reflect a combination of environmental changes (Conboy et al. 2003, 2005; Brack et al. 2007; Carlson et al. 2008), cell-intrinsic changes in stem cell regulation (Janzen et al. 2006; Krishnamurthy et al. 2006; Molofsky et al. 2006), and the accumulation of genetic and epigenetic damage within stem cells (Rossi et al. 2007). Stem cell self-renewal programs must therefore change during aging to cope with these environmental changes, to adjust to the changing demands of tissue homeostasis, and to avoid transformation (Table 1). 
We review evidence that self-renewal programs differ among embryonic, fetal, young adult, and old adult stem cells. Our goal is not to comprehensively review selfrenewal mechanisms but rather to focus on a subset of key age-specific mechanisms. To accomplish this, we focus primarily on embryonic stem (ES) cells, germ-line stem cells, HSCs, and neural stem cells.

\section{EMBRYONIC STEM CELL SELF-RENEWAL}

The zygote is totipotent and can form all lineages of the embryo including the extraembryonic trophectoderm and primitive endoderm. It is not clear whether totipotent stem cells self-renew in vivo as cells begin to specialize within the embryo by the 32 -cell stage ( 3 days in mice) (Johnson and McConnell 2004). By implantation (4 days in mice), the blastocyst includes the extraembryonic trophectoderm as well as the embryonic inner cell mass (Yamanaka et al. 2006). The inner cell mass contains epiblast cells that when cultured give rise to pluripotent ES cell lines. ES cells self-renew indefinitely in culture and are pluripotent, giving rise to cells of all three germ layers, although they are not totipotent because they are unable to form extraembryonic tissues. Epiblast cells exist only in a limited window of development and although these cells must maintain pluripotency, it is not clear whether they actually execute self-renewing divisions in vivo. It is thus possible that the in vitro ES cell self-renewal program incorporates mechanisms that regulate pluripotency in vivo, whereas other aspects of the self-renewal program are acquired in culture.

Oct4, Nanog, and Sox 2 are transcription factors that compose a core regulatory circuit required for ES cell pluripotency and self-renewal (Jaenisch and Young 2008). These three proteins bind and autoregulate their own promoters, regulate the expression of other pluripotency genes, and repress early differentiation genes (Nichols et al. 1998; Boyer et al. 2005; Loh et al. 2006; Wang et al. 2006; Masui et al. 2007). Nanog stabilizes the pluripotent state, reduces the propensity of ES cells to spontaneously differentiate, and is required for ES cells to contribute to the germ line (Chambers et al. 2007). Nanog, Oct4, and Sox2 induction also reprograms adult cells to pluripotency (Takahashi and Yamanaka 2006; Takahashi et al. 2007; Yu et al. 2007b; Park et al. 2008).

These core transcriptional regulators do not control selfrenewal on their own. Caspase- 3 is an intracellular protease that is activated during apoptosis and in ES cells upon differentiation. Caspase- 3 is necessary and sufficient for ES cell differentiation, promoting this in part through the proteolytic cleavage of Nanog (Fujita et al. 2008). The discovery that caspase- 3 regulates ES cell differentiation led to the discovery of Ronin. Ronin is a zinc finger DNAbinding protein that is also necessary and sufficient for ES cell self-renewal. Like Nanog, Ronin is cleaved by caspase-3 during differentiation (Dejosez et al. 2008). Ronin acts with other proteins to epigenetically repress gene expression independently of Oct4, Sox2, and Nanog. Thus, multiple pathways independently regulate ES cell self-renewal and pluripotency, and caspase- 3 activity attenuates at least two of these to initiate differentiation.

Oct4, Nanog, Sox2, and Ronin are also required for the formation of the inner cell mass in vivo. Oct4 expression is restricted to the inner cell mass during early embryonic development and is rapidly shut off as differentiation occurs (Lengner et al. 2007). Oct4-deficient embryos fail to develop beyond the blastocyst stage and lack a pluripotent inner cell mass, which instead gives rise to extraembryonic trophoblast cells (Nichols et al. 1998). Nanog expression is largely restricted to the inner cell mass and early germ-line cells (Chambers et al. 2003; Mitsui et al. 2003). Nanog-deficient embryos fail to develop beyond the blastocyst stage and lack pluripotent epiblasts, although Nanog-deficient ES cells can contribute widely to somatic tissues outside of the germ line (Chambers et al. 2003; Mitsui et al. 2003). Sox2-deficient embryos also lack pluripotent epiblast cells (Avilion et al. 2003). Ronin expression is primarily detected within the inner cell mass. Ronin deficiency leads to peri-implantation lethality and prevents pluripotent cells from growing out of the

Table 1. Examples of genes that regulate stem cell self-renewal at distinct developmental stages

\begin{tabular}{|c|c|c|c|}
\hline Gene & Gene product & Stem cells & References \\
\hline Nanog & homeodomain transcription factor & ES cells & Mitsui et al. (2003); Chambers et al. (2007) \\
\hline Pouf1/Oct 4 & Pou domain transcription factor & ES cells & Nichols et al. (1998); Lengner et al. (2007) \\
\hline Thap11/Ronin & Thap domain epigenetic regulator & ES cells & Dejosez et al. (2008) \\
\hline Caspase-3 & protease & ES cells, HSCs & Fujita et al. (2008); Janzen et al. (2008) \\
\hline & zinc finger transcription factor & ES cells, HSCs & Galan-Caridad et al. (2007) \\
\hline Sox17 & transcription factor & fetal HSCs & Kim et al. (2007) \\
\hline Hmga2 & chromatin regulator & $\begin{array}{l}\text { fetal and young adult neural } \\
\text { stem cells }\end{array}$ & Nishino et al. (2008) \\
\hline Bmi-1 & Polycomb epigenetic regulator & many adult stem cells & $\begin{array}{l}\text { Lessard and Sauvageau (2003); Molofsky et } \\
\text { al. (2003); Park et al. (2003) }\end{array}$ \\
\hline Klotho & Wnt Inhibitor & old HSCs, satellite muscle cells & Liu et al. (2007) \\
\hline Angiopoietin-1 & cytokine & adult HSCs & Puri and Bernstein (2003); Arai et al. (2004) \\
\hline thrombopoietin & cytokine & adult HSCs & Qian et al. (2007); Yoshihara et al. (2007) \\
\hline Gfi-1 & transcription factor & adult HSCs & Hock et al. (2004a) \\
\hline Tel/Etv6 & transcription factor & adult HSCs & Hock et al. (2004b) \\
\hline let-7b & microRNA & old neural stem cells & Nishino et al. (2008) \\
\hline$p 16^{\operatorname{Ink} 4 a}$ & cyclin-dependent kinase inhibitor & many old stem cells & $\begin{array}{l}\text { Janzen et al. (2006); Krishnamurthy et al. } \\
\text { (2006); Molofsky et al. (2006) }\end{array}$ \\
\hline
\end{tabular}


inner cell mass in culture (Dejosez et al. 2008). These studies demonstrate that aspects of the ES cell selfrenewal program that are required in culture are also required for the formation of the inner cell mass and for epiblast pluripotency in vivo.

Other genes that are required for the self-renewal of ES cells in culture are not necessary for the generation of the inner cell mass in vivo. Standard protocols for the derivation and propagation of ES cells use leukemia inhibitory factor (LIF), which promotes self-renewal by activating STAT3 (signal transducer and activator of transcription 3) via the gp130 receptor (Niwa et al. 1998; Ying et al. 2003). Although these genes are required for the self-renewal of ES cells in vitro, LIF and gp130 are dispensable for embryonic development in vivo (Li et al. 1995; Ware et al. 1995; Yoshida et al. 1996; Dani et al. 1998). The requirement for LIF signaling in culture may reflect the need to block differentiation-inducing cues in culture that do not exist in vivo; addition of chemical inhibitors of fibroblast growth factor-4 (FGF-4)-induced ERK (extracellular signal-regulated kinase) phosphorylation can maintain the pluripotency of ES cells in the absence of LIF and serum (Ying et al. 2008). A series of transcriptional regulators including Tbx3, Tcl1, and Esrrb (Ivanova et al. 2006) as well as Zfx (Galan-Caridad et al. 2007) are also required for ES cell self-renewal in culture but not early embryonic development in vivo. These studies illustrate the context dependence of self-renewal programs and the fact that mechanisms required for self-renewal in culture do not necessarily regulate pluripotency or self-renewal under physiological conditions in vivo.

Some key elements of the pluripotent self-renewal program are restricted to ES cells and epiblast cells, whereas others are not. Although Nanog and Oct4 regulate the maintenance of pluripotency in ES cells and epiblast cells, they are not required for the function of fetal or adult somatic stem cells (Chambers et al. 2007; Lengner et al. 2007). Sox 2, on the other hand, is expressed by fetal and adult neural stem cells and is required for their selfrenewal (Graham et al. 2003; Suh et al. 2007). Caspase-3 deficiency increases adult HSC numbers (Janzen et al. 2008) just as it promotes the maintenance of ES cells (Fujita et al. 2008). The Zfx transcription factor provides a particularly interesting example because it is required for the self-renewal of adult (but not fetal) HSCs in addition to ES cells (Galan-Caridad et al. 2007). It is not yet clear whether Ronin regulates somatic stem cell function. These studies demonstrate that although elements of the pluripotent stem cell self-renewal program can be used by somatic stem cells at later stages of development, other features seem to uniquely define the pluripotent state.

\section{FETAL AND NEONATAL STEM CELL SELF-RENEWAL}

Fetal development represents a distinct stage marked by tissue specialization and tremendous growth. Consistent with this, the pluripotent cells of the embryo are replaced by a series of tissue-specific multipotent stem cells with developmental potentials that match the demands of their growing tissues. As a result, fetal self- renewal programs acquire tissue-specific components that regulate multipotency and differentiation in response to tissue-specific cues. But although the developmental potential of fetal somatic stem cells is narrower than their embryonic progenitors, fetal stem cells remain highly mitotically active. HSCs from the fetal liver (Morrison et al. 1995) and neural crest stem cells from the developing peripheral nervous system (Morrison et al. 1999; Bixby et al. 2002) divide rapidly in vivo and appear to undergo frequent self-renewing divisions. The absolute numbers of stem cells in many tissues expand considerably during fetal development, and imaging of progenitor divisions suggests that this expansion is driven initially by symmetric self-renewing divisions, followed by asymmetric divisions that generate differentiated progeny (Chenn and McConnell 1995; Lechler and Fuchs 2005; Morrison and Kimble 2006). Fetal self-renewal programs must therefore change relative to embryonic self-renewal to account for tissue specialization as well as developmental changes in the symmetry of division.

\section{Fetal Germ-line Stem Cells}

The existence of fetal-specific self-renewal programs is illustrated by spermatogonial stem cells (Oatley and Brinster 2008). Primordial germ cells are specified from epiblast cells early in embryogenesis, then migrate to the genital ridges by E11.5. Primordial germ cells cycle rapidly and expand their numbers from 100 cells at E8.5 to 25,000 cells at E13.5. Once in the genital ridges, primordial germ cells form gonocytes that commit to a sexspecific fate. In male testis, fetal gonocytes briefly stop dividing, but they resume self-renewal by postnatal day 3 when they become spermatogonial stem cells.

This lineage illustrates the changes in fetal self-renewal programs that occur over time. Nanos 3 and Nanos 2 encode zinc finger proteins, thought to act as RNA-binding translational repressors, that are required for the maintenance/expansion of primordial germ cells and gonocytes, respectively (Tsuda et al. 2003). Nanos3 is expressed in primordial germ cells as early as E7.5, whereas Nanos2 is only detected in gonocytes after colonization of the genital ridges. In the absence of Nanos3, the number of primordial germ cells is normal at E7.5 but depleted by E15.5. In the absence of Nanos2, primordial germ cell numbers are normal at E14.5 but no spermatogonial stem cells are present in the testis by 4 weeks after birth. Nanos 3 is required to prevent cell death during primordial germ cell migration (Suzuki et al. 2008). Nanos 2 is required for specification of male-specific germ cell fate (Suzuki and Saga 2008) in addition to gonocyte survival (Tsuda et al. 2003). These results show that Nanos 3 and Nanos 2 are dispensable for the specification of primordial germ cells but are sequentially required for the maintenance of germ-line stem cells during development. Although Nanos 3 and Nanos 2 are required by germ-line stem cells during development, mice lacking these genes have no other overt phenotype, suggesting that Nanos 3 and Nanos 2 are not required by other somatic stem cells (Tsuda et al. 2003). The genes that Nanos 3 and Nanos2 repress in order to ensure stem cell maintenance are not yet known. 


\section{Fetal and Neonatal Hematopoietic Stem Cells}

Fetal and neonatal HSCs have a unique self-renewal program that depends on the Sox 17 transcriptional regulator (Kim et al. 2007). Sox 17 is a Sox family high-mobility-group transcription factor that is expressed in fetal and neonatal HSCs but is absent from adult HSCs. Conditional deletion of Sox 17 in fetal mice using Tie2Cre or in neonatal mice using $M x-1-C r e$ led to the rapid depletion of HSCs and hematopoietic failure (Fig. 1). However, when Sox 17 was conditionally deleted from HSCs using Mx-1-Cre 6 weeks after birth, no defect was observed in HSC frequency, function, or hematopoiesis. These findings demonstrate that Sox 17 is required for the maintenance of fetal and neonatal HSCs but not adult HSCs. This demonstrates that there is a distinct fetal/neonatal HSC self-renewal program and raises the question of what program takes over for the maintenance of adult HSCs. Additional experiments are required to elucidate the mechanisms by which Sox 17 promotes HSC maintenance.

Sox17 is also a marker of fetal identity in HSCs. Sox17 is expressed by all fetal and neonatal HSCs but by less than $1 \%$ of other cells in the fetal liver or neonatal bone marrow (Fig. 1A). At 3-4 weeks after birth, HSCs go through a concerted developmental change in which they transition from a rapidly dividing fetal phenotype to a slowly dividing adult phenotype (Bowie et al. 2006, 2007). This is also when Sox17 expression is extinguished by HSCs (Kim et al. 2007). Moreover, examination of HSCs in the middle of this transition shows that the Sox $17^{+}$subset retains fetal characteristics, whereas the Sox $17^{-}$subset in the same bones of the same mice have acquired adult characteristics (see Fig. 1D). A key transcriptional regulator of HSC identity and function thus changes between the fetal and young adult stages.
A

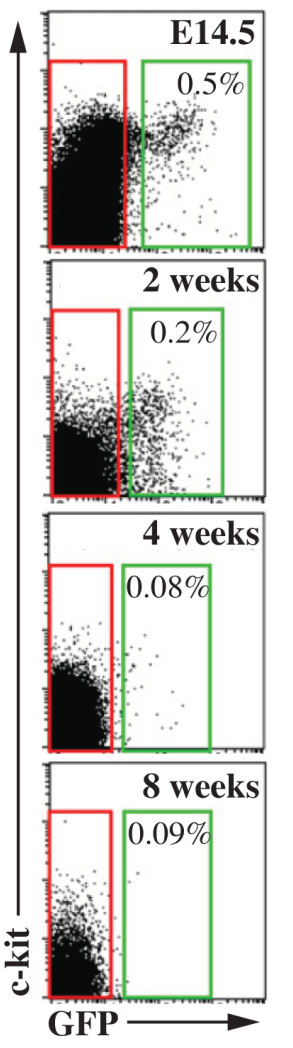

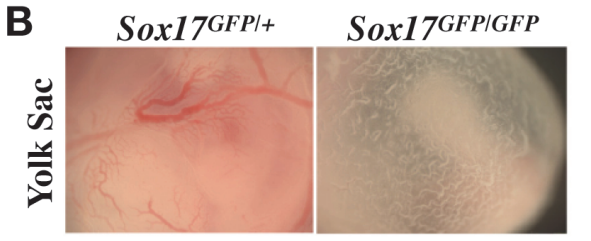
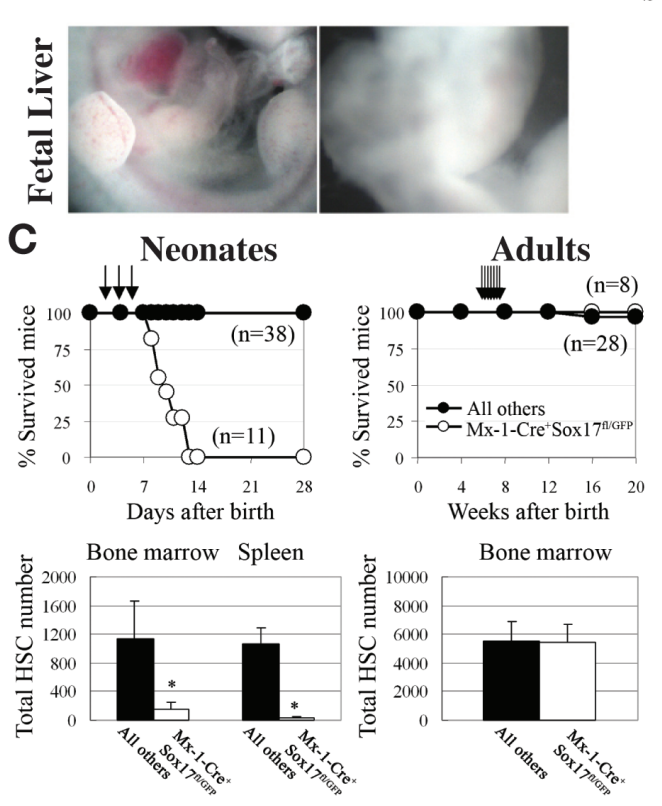
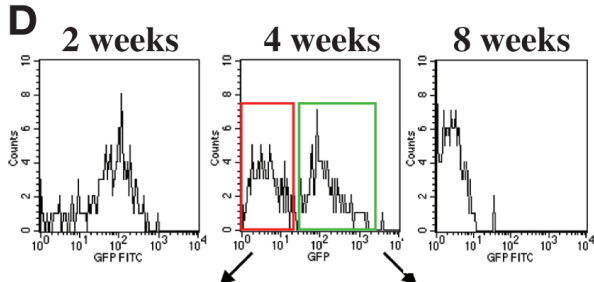

GFP- HSCs
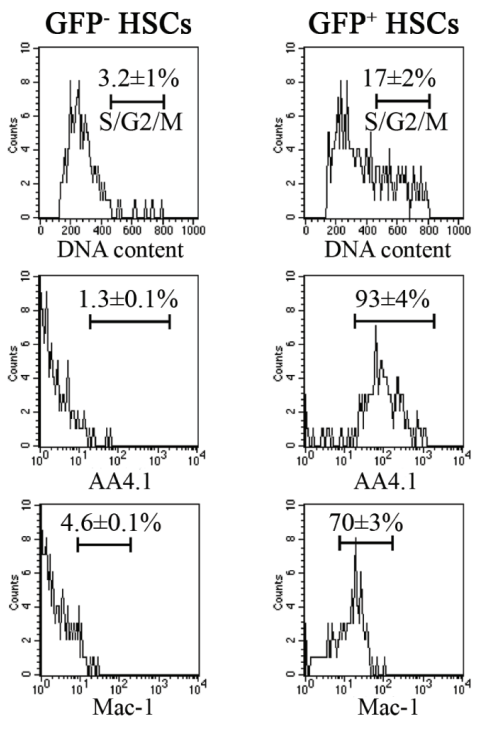

Figure 1. Sox 17 is required for the self-renewal of fetal HSCs but not adult HSCs. (A) Green fluorescent protein (GFP) and c-Kit expression from unfractionated fetal liver or bone marrow cells analyzed by flow cytometry from Sox $17^{G F P /+}$ mice. Boxes indicate $\mathrm{GFP}^{-}$(red) and $\mathrm{GFP}^{+}$(green) cells. GFP ${ }^{+}$cells represented fewer than $1 \%$ of cells in the fetal liver and were no longer detectable 8 weeks after birth in the bone marrow. $(B)$ E11.5 embryos that lack Sox 17 (Sox $\left.17^{G F P / G F P}\right)$ have a near-complete lack of hematopoiesis in the yolk sac or embryo. (C) Sox 17 was conditionally deleted (in $M x-1-C r e^{+}$Sox $17^{f l / G F P}$ mice) to test its role in hematopoiesis in neonatal (left) or young adult (right) mice. Although all neonatal mice died within 1 week of Sox17 deletion, Sox 17 deficiency did not affect the viability of young adult mice. After Sox 17 deletion, HSCs were dramatically depleted in the bone marrow and spleen of neonatal mice, whereas HSCs were unaffected in young adult mice. (D) HSCs uniformly express Sox 172 weeks after birth but uniformly lack expression by 8 weeks after birth (inferred based on GFP expression from the Sox $17^{G F P}$ knockin allele). Four weeks after birth, when HSCs are making the transition from a fetal to an adult phenotype, half of the HSCs express Sox 17. The Sox 17 expressing HSCs are rapidly dividing and express fetal HSC markers, whereas the subset of HSCs that lack Sox17 expression are slowly dividing and express adult HSC markers. These results suggest that Sox17 is a marker of fetal/neonatal identity in HSCs. (Reprinted from Kim et al. 2007 [C Cell Press].) 


\section{Fetal Neural Stem Cells}

Multipotent and self-renewing central nervous system (CNS) stem cells first arise in the context of the embryonic neuroepithelium. As neurogenesis begins, stem cells acquire a radial glial morphology with cell bodies in the ventricular zone and long processes that extend to the pial surface (Anthony et al. 2004). These radial glia often appear to divide asymmetrically, forming a radial glial daughter as well as a daughter cell fated to undergo neuronal differentiation (Noctor et al. 2004). Many of the daughter cells fated to form neurons amplify their progeny through subsequent symmetric divisions (Miyata et al. 2002; Haubensak et al. 2004; Noctor et al. 2004). Radial glial cells persist in the ventricle zone until the postnatal appearance of adult neural stem cells in a subventricular zone (Doetsch et al. 1999; Imura et al. 2003; Garcia et al. 2004). Lineage mapping has shown that adult neural cells are derived from fetal radial glial cells (Merkle et al. 2004). Neural stem cells thus undergo changes in their morphology and localization throughout fetal development.

Neural stem cells are fated to form an array of progeny at different stages of fetal development, starting with different types of neurons and ending with gliogenesis (Temple 2001). These changes in fate are likely regulated by both environmental and stem-cell-intrinsic changes that occur over time. In support of this, neural progenitors that are heterochronically transplanted into the CNS of older recipients form neurons appropriate to the age of their new environment, but older progenitors cannot form earlier subtypes of neurons upon transplantation into a younger developing forebrain (Frantz and McConnell 1996; Desai and McConnell 2000). This neuronal fate restriction is controlled by several components including FoxG1. FoxG1 is expressed by neural progenitors after the production of layer-1 neurons and represses layer-1 neuronal fate. Deletion of FoxG1 causes layer-1 neurons to be continually produced during later developmental stages, where they are normally no longer produced (Hanashima et al. 2004; Shen et al. 2006).

The narrowing of neuronal subtype potential that occurs during cortical development suggests that multipotent forebrain cells do not generate identical progeny when they self-renew. Indeed, neural stem cells appear to undergo developmental restrictions throughout life but retain multipotency and proliferative potential. The observation that neural stem cells depend on many of the same self-renewal mechanisms that are used by HSCs (and that even HSCs undergo developmental changes in lymphocyte subtype potential over time) suggests that they depend on a core "self-renewal" program despite the fact that developmental potential changes over time. Existing data suggest that this core self-renewal program can be modified by factors that restrict neuronal subtype potential (or lymphocyte subtype potential in the case of HSCs). Self-renewal mechanisms are therefore not necessarily designed to generate identical progeny but rather to generate undifferentiated progeny that remain multipotent and self-renewing.

\section{ADULT STEM CELL SELF-RENEWAL}

Adult stem cells exhibit several differences relative to fetal stem cells that affect the regulation of self-renewal. In contrast to the rapid division of fetal stem cells, adult stem cells are often relatively quiescent. Adult mouse HSCs are quiescent most of the time, although all HSCs appear to enter the cycle on a regular basis and contribute to hematopoiesis (Cheshier et al. 1999; Kiel et al. 2007). As a result, adult self-renewal programs commonly feature mechanisms that promote quiescence. Adult stem cells often have less self-renewal potential than fetal stem cells from the same tissue. HSCs and neural crest stem cells from fetal mice have more self-renewal potential than those from adult mice (Chen et al. 2000; Kruger et al. 2002). Differences in self-renewal programs must therefore account for the difference in self-renewal potential. Finally, adult stem cells often have a narrower developmental potential than fetal stem cells in the same tissues. Adult HSCs remain multipotent and capable of generating lymphocytes but they lose the ability to make certain subtypes of lymphocytes that are only made by fetal HSCs (Hayakawa et al. 1985; Ikuta et al. 1990; Kantor et al. 1992). Neural crest stem cells from the adult gut remain multipotent and able to make neurons, but they lose the ability to make certain subtypes of neurons that are only made in the fetal gut (Kruger et al. 2002). As a result, multipotency of adult stem cells differs from that of fetal stem cells. For all of these reasons, self-renewal programs must be regulated differently in adult stem cells as compared to fetal stem cells.

\section{Adult Germ-line Stem Cells}

Cell signaling and transcriptional regulation distinguish the self-renewal of adult spermatogonial stem cells from their fetal counterparts. Glial-cell-line-derived neurotrophic factor (GDNF) is critical for the self-renewal of spermatogonial stem cells but not for the expansion of their fetal progenitors. Sertoli cells in the testis secrete GDNF (Tadokoro et al. 2002), whereas the spermatogonial stem cells express the GDNF coreceptors Ret and GFRA1 (Naughton et al. 2006). In the absence of Gdnf, Ret, or Gfral, primordial germ cells colonize the testis normally and are present in normal numbers at birth, but spermatogonial stem cells fail to self-renew postnatally and become depleted (Naughton et al. 2006). Adult spermatogonial stem cells also require the zinc finger transcription factor Plzf (Buaas et al. 2004; Costoya et al. 2004) and the TFIID RNA polymerase complex component Taf4b (Falender et al. 2005). Mice lacking these genes exhibit normal spermatogonial development and initially produce mature sperm, but spermatogonial stem cells fail to self-renew and spermatogenesis is depleted (Costoya et al. 2004; Falender et al. 2005). Extrinsic and intrinsic factors that control spermatogonial stem cell self-renewal thus differ between adult and fetal stages.

\section{Adult Hematopoietic Stem Cells}

Many self-renewal mechanisms are conserved between fetal and adult HSCs. A number of transcriptional regula- 
tors including Rae28 (Ohta et al. 2002; Kim et al. 2004b), Meis1 (Hisa et al. 2004; Kirito et al. 2004; Azcoitia et al. 2005), c-Myb (Mucenski et al. 1991; Sandberg et al. 2005), Cbp (Rebel et al. 2002), Gata-2 (Tsai et al. 1994; Rodrigues et al. 2005), PU.1 (Kim et al. 2004a; Iwasaki et al. 2005), and Mll (McMahon et al. 2007) are required for the self-renewal of both fetal and adult HSCs. This demonstrates that self-renewal programs do not undergo wholesale changes between fetal development and adulthood but rather are modified to account for developmental differences in stem cell function.

Nonetheless, there are key differences in self-renewal regulators among fetal and adult HSCs. One prominent example is Bmi-1, which is consistently required for the self-renewal of all postnatal stem cell populations examined so far, including HSCs and neural stem cells (Lessard and Sauvageau 2003; Molofsky et al. 2003; Park et al. 2003). Bmi-1 is a proto-oncogene and a component of the Polycomb repressive complex 1 that regulates chromatin structure by recruiting epigenetic regulators to specific loci (Valk-Lingbeek et al. 2004). Bmi-1 is not required for the formation or maintenance of stem cells during fetal development because Bmi-1-deficient mice are born with normal numbers of stem cells. Rather, Bmi1-deficient stem cells exhibit a postnatal self-renewal defect that leads to the depletion of stem cells by early adulthood. By postnatal day 30, HSCs are depleted from the bone marrow of Bmi-1-deficient mice, and bone marrow cells from these mice are unable to reconstitute irradiated recipient mice (Park et al. 2003). Bmi-1-deficient mice generally die by postnatal day 30 , exhibiting growth retardation, hematopoietic failure, and neurological problems (ataxia, seizures) (van der Lugt et al. 1994).

One major mechanism by which Bmi-1 promotes the self-renewal of HSCs and other postnatal stem cell populations is through repression of the $\mathrm{p} 16^{\text {Ink4a }}$ and $\mathrm{p} 19^{\text {Arf }}$ tumor suppressors (Fig. 2) (Jacobs et al. 1999; Bruggeman et al. 2005; Molofsky et al. 2005; Akala et al. 2008). p16 ${ }^{\text {Ink4a }}$ is a cyclin-dependent kinase inhibitor that promotes $\mathrm{Rb}$ (retinoblastoma) activation, slowing cell cycle progression or inducing cellular senescence (Lowe and Sherr 2003). p19 ${ }^{\text {Arf }}$ promotes p53 activity, also slowing cell cycle progression or inducing cellular senescence. $\mathrm{p} 16^{\text {Ink4a }}$ and $\mathrm{p} 19^{\text {Arf }}$ expression generally cannot be detected in fetal or young adult tissue, but these gene products are readily detected in postnatal stem cells in the absence of Bmi-1 (Molofsky et al. 2003; Park et al. 2003). Deletion of $p 16^{\text {Ink4a }}$ and/or $p 19^{A r f}$ partially rescues the self-renewal defects observed in various stem cell populations, including HSCs and neural stem cells (Jacobs et al. 1999; Bruggeman et al. 2005; Molofsky et al. 2005; Oguro et al. 2006; Akala et al. 2008). These results demonstrate that repression of $p 16^{\text {Ink4a }}$ and $p 19^{A r f}$ is a fundamental requirement for the maintenance of adult stem cells.

Additional transcriptional regulators also distinguish adult from fetal HSC self-renewal. Gfil (Hock et al. 2004a), Tel/Etv6 (Hock et al. 2004b), and FoxO (Miyamoto et al. 2007; Tothova et al. 2007) gene products are all required for the maintenance of adult but not fetal HSCs. Gfil promotes the quiescence of adult HSCs, whereas Tel/Etv6 promotes their survival. FoxO tran-
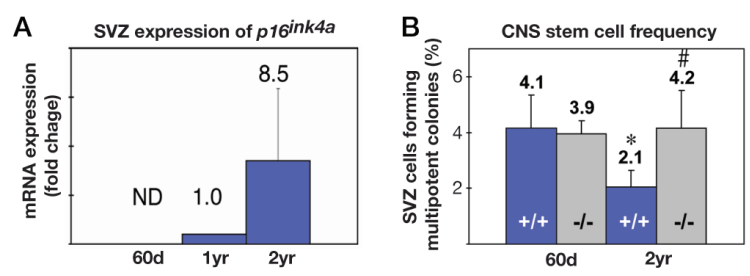

C p16ink4a+/+
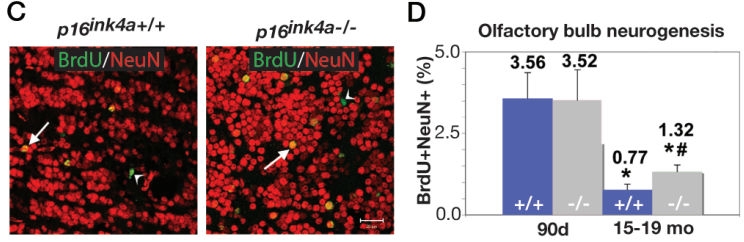

Figure 2. $\mathrm{p} 16^{\text {Ink4a }}$ expression increases with age and negatively regulates stem cell frequency and function. $(A) \mathrm{p} 16^{\text {Ink4a }}$ expression increases with age in uncultured subventricular zone cells. $(B)$ The decline in stem cell frequency during aging is at least partially rescued by $p 16^{\text {Ink } 4 a}$ deficiency. $(C, D)$ The decline in olfactory bulb neurogenesis during aging is partially rescued by p $16^{\text {Ink4a }}$ deficiency (based on the frequency of bromodeoxyuridine $[\mathrm{BrdU}]$-containing $\mathrm{NeuN}^{+}$neurons in the olfactory bulb). (Reprinted from Molofsky et al. 2006 [C Nature Publishing Group].)

scription factors promote the expression of enzymes that reduce levels of reactive oxygen species, such that in the absence of FoxO function, reactive oxygen species accumulate and HSCs are depleted. These results emphasize the importance of diverse transcription factors to regulate the maintenance of stem cell integrity in a developmentally regulated manner.

Fetal and adult HSCs also differ in their dependence on growth factors and signaling molecules. Thrombopoietin and its receptor $\mathrm{Mpl}$ promote the quiescence and maintenance of adult HSCs, but neither gene is required for the maintenance of fetal HSCs (Qian et al. 2007; Yoshihara et al. 2007). Angiopoietin-1 and its receptor Tie 2 are similarly reported to promote the quiescence and maintenance of adult HSCs, but they are not required for the maintenance of fetal HSCs (Puri and Bernstein 2003; Arai et al. 2004). The ligands thrombopoietin and angiopoietin-1 are expressed in the bone marrow, and their corresponding receptors are expressed on HSCs. These results demonstrate that both cell-extrinsic and -intrinsic components of signaling networks regulate differences in stem cell maintenance between fetal and adult HSCs.

\section{Adult Neural Stem Cells}

Neural stem cells are maintained throughout adult life in two regions of the CNS and in at least two regions of the peripheral nervous system (PNS). Within the CNS, stem cells are maintained in the lateral wall of the lateral ventricle (Doetsch et al. 1999; Sanai et al. 2004) where they undergo neurogenesis throughout life, forming interneurons that migrate into the olfactory bulb (Sawamoto et al. 2006; Curtis et al. 2007). These new interneurons synapse on the projection neurons that connect the olfactory bulb to the cortex and likely regulate the ability to learn to discriminate chemically similar odor- 
ants (Magavi et al. 2005; Alonso et al. 2006). Stem cells also persist through adult life in the subgranular layer of the dentate gyrus (Palmer et al. 1997) where they form interneurons (Eriksson et al. 1998; van Praag et al. 2002). The new neurons that incorporate into the adult dentate gyrus appear to regulate certain forms of spatial learning and memory (Shors et al. 2001; Zhang et al. 2008). Within the PNS, multipotent and self-renewing neural crest stem cells persist throughout adult life in the wall of the gut (Kruger et al. 2002), although the physiological function of these stem cells remains unclear. A distinct neuralcrest-derived stem cell population persists throughout life in the carotid body, where it gives rise to new glomus cells in response to oxygen stress (Pardal et al. 2007).

Just as in the hematopoietic system, some components of the neural stem cell self-renewal program are required by stem cells at all stages of development. For example, the Sox 2 transcriptional regulator that is required for ES cell self-renewal is also required for the maintenance of undifferentiated neural stem cells at all stages from embryonic development through adulthood (Pevny and Placzek 2005). A loss of Sox 2 function causes premature differentiation and depletion of neural stem cells at both fetal and adult stages, with a consequent impairment of neurogenesis (Bylund et al. 2003; Graham et al. 2003; Ferri et al. 2004). Sox 2 is not alone in this regard because Numb and Numblike also appear to be required throughout fetal and adult life for the self-renewal of forebrain neural stem cells (Petersen et al. 2002, 2004; Shen et al. 2002; Kuo et al. 2006).

Some gene products are required throughout life by stem cells, but their precise function may change in concert with developmental changes in stem cells. For example, the orphan nuclear receptor Tlx is required to regulate cell cycle progression and fate determination within fetal and adult neural progenitors (Miyawaki et al. 2004; Roy et al. 2004; Shi et al. 2004); however, the precise ways in which these progenitors depend on Tlx varies depending on the location and time during development. In the retina, Tlx is required to regulate the proliferation of progenitors during fetal development and then to regulate glial differentiation postnatally (Miyawaki et al. 2004). In the developing cortex, Tlx is required to promote proliferation and to delay neurogenesis by ventricular zone progenitors, such that in the absence of Tlx, undifferentiated cells become depleted by premature neurogenesis and outer layers of cortical neurons are severely reduced (Roy et al. 2004). Within the adult subventricular zone, Tlx is required by stem cells to maintain self-renewal potential and to avoid premature glial differentiation (Shi et al. 2004). Thus, the way in which stem cells use Tlx to retain an undifferentiated state changes with location and time during development.

Other key transcriptional regulators are required by adult but not fetal stem cells. In the absence of Bmi-1, mice are born with normal numbers of neural stem cells, but p1 $6^{\text {Ink4a }}$ and $\mathrm{p} 19^{\text {Arf }}$ become derepressed postnatally, leading to the depletion of stem cells and neurogenesis from the CNS and PNS (Molofsky et al. 2003, 2005; Bruggeman et al. 2005). This demonstrates that neural stem cells share with HSCs a common dependence on transcriptional regu- latory mechanisms that distinguish adult stem cell maintenance from fetal stem cell maintenance.

\section{AGING STEM CELL SELF-RENEWAL}

Stem cells must persist throughout life in numerous tissues to maintain tissue regenerative capacity. Yet, these cells must cope with ongoing change during adulthood. Genetic and epigenetic damage accumulates throughout life from reactive oxygen species, radiation, and chemical exposure. This damage impairs cellular function. For example, mitochondria accumulate damage with age, leading to a decline in mitochondrial function (Guarente 2008). Cells must compensate for this damage and declining function. In concert, the risk of neoplastic transformation increases with age as mutations accumulate. Cells must counteract this by augmenting tumor suppressor mechanisms during aging. Finally, there are systemic and local environmental changes within tissues during aging to which stem cells must adapt. For all of these reasons, stem cell self-renewal mechanisms change during aging.

\section{Aging Hematopoietic Stem Cells}

The properties of HSCs change in several ways as these cells age. The frequency of HSCs changes with age, although the nature of the change depends on the mouse strain: In some strains, such as C57BL, HSCs expand in number during aging (Morrison et al. 1996; Sudo et al. 2000; Yilmaz et al. 2006), whereas in other strains, HSCs become depleted during aging (de Haan and Van Zant 1999; Geiger and Van Zant 2002). HSC cell cycle status also changes during aging in a strain-dependent manner, with C57BL HSCs exhibiting increased cycling (Morrison et al. 1996; de Haan et al. 1997; Yilmaz et al. 2006). Aging HSCs also acquire an engraftment defect in which individual old HSCs are only one-third as likely as young HSCs to engraft in young irradiated recipient mice after transplantation (Morrison et al. 1996; Liang et al. 2005; Yilmaz et al. 2006). Nonetheless, individual reconstituting HSCs give similar overall levels of reconstitution, irrespective of whether they are from young or old donors. Finally, fate determination is affected because HSC differentiation appears skewed toward the production of myeloid cells at the expense of lymphoid cells in old mice (Morrison et al. 1996; Liang et al. 2005; Rossi et al. 2005). HSCs thus undergo many cell-intrinsic alterations in their functional properties during aging.

Despite ongoing Bmi-1 expression, $\mathrm{p} 16^{\text {Ink4a }}$ is induced in aging stem cells, reducing the cells' self-renewal potential (Janzen et al. 2006). p16 ${ }^{\text {ink4a }}$ is expressed by HSCs from old, but not young, mice. p16 $6^{\text {ink4a }}$ deficiency does not affect HSCs from young mice, but it increases the frequency, survival, self-renewal, and repopulating ability of HSCs from old mice. $\mathrm{p} 16^{\text {ink4a }}$ expression thus distinguishes old HSCs from young HSCs, demonstrating that the self-renewal of stem cells during aging is modified by increased tumor suppressor function. p19 Arf expression also increases with age in a variety of tissues (Krishnamurthy et al. 2004), but whether $\mathrm{p} 19^{\text {Arf }}$ regulates stem cell aging has not yet been tested. 


\section{Aging Neural Stem Cells}

Neural stem cell frequency, self-renewal capacity, and mitotic activity all decline with age, along with the rate of neurogenesis (Enwere et al. 2004; Maslov et al. 2004; Molofsky et al. 2006). These declines in neural stem cell frequency and function are partially caused by increasing p $16^{\text {Ink4a }}$ expression. p16 ${ }^{\text {Ink4a }}$ generally cannot be detected in fetal and young adult tissues but is induced in a variety of aging tissues (Fig. 2A) (Zindy et al. 1997; Krishnamurthy et al. 2004; Molofsky et al. 2006). p1 $6^{\text {Ink4a }}$ deficiency partially rescues the decline in stem cell frequency (Fig. 2B), self-renewal potential, and neurogenesis in the aging CNS without affecting stem cell function or neurogenesis in the young adult CNS (Fig. 2C,D) (Molofsky et al. 2006). The decline in stem cell function at least partially reflects an active process in which tumor suppressors are induced during aging. Because $p 16^{\text {Ink4a }}$ deficiency also leads to early onset and increased incidence of malignancies, stem cells may induce $\mathrm{p} 16^{\text {Ink4a }}$ expression during aging to avoid neoplastic transformation. This raises the possibility that stem cells balance regenerative (self-renewal) capacity with the risk of transformation during aging and that the induction of tumor suppressors during aging is a compromise designed to delay the onset of cancer.

The results described above raised two questions. First, why do old adult stem cells express higher levels of $\mathrm{p} 16^{\text {Ink4a }}$ and $\mathrm{p} 19^{\text {Arf }}$ than fetal and young adult stem cells? Second, given that Bmi-1 does not regulate $\mathrm{p} 16^{\text {Ink4a }}$ and $\mathrm{p} 19^{\text {Arf }}$ expression by fetal stem cells in vivo (Molofsky et al. 2003), are there other mechanisms that repress $p 16^{\text {Ink4a }}$ and $\mathrm{p} 19^{\text {Arf }}$ in fetal stem cells? We have recently discovered that the high-mobility-group transcriptional regulator Hmga 2 is highly expressed in fetal neural stem cells, but expression declines in young adult stem cells and is extinguished in old adult stem cells (Fig. 3A) (Nishino et al. 2008). This decrease in expression is partly caused by the increasing expression of let-7b microRNA, which is known to target Hmga2 (Fig. 3F) (Lee and Dutta 2007; Mayr et al. 2007; Yu et al. 2007a). Hmga2-deficient mice show reduced stem cell frequency and self-renewal potential throughout the CNS and PNS of fetal and young adult mice, but not old adult mice (Fig. 3D) (Nishino et al. 2008). Furthermore, $\mathrm{p} 16^{\text {Ink4a }}$ and $\mathrm{p} 19^{\text {Arf }}$ expression is increased in Hmga2-deficient fetal and young adult stem cells, and deletion of $p 16^{\text {Ink4a }}$ and/or $p 19^{A r f}$ partially restores their self-renewal capacity (Fig. 3B,C). Hmga2 thus promotes stem cell self-renewal during early life by decreasing $\mathrm{p} 16^{\text {Ink4a }} / \mathrm{p} 19^{\text {Arf }}$ expression. These results identify a new pathway that regulates stem cell aging in which let- $7 b$ expression increases with age, reducing Hmga2 expression and increasing $\mathrm{p} 16^{\text {Ink } 4 \mathrm{a}} / \mathrm{p} 19^{\text {Arf }}$ expression, leading to reduced stem cell function (Fig. 3G).

The requirement for Hmga2 in fetal and young adult stem cells, along with the requirement for Bmi-1 in young and old adult stem cells, demonstrates that there are overlapping transcriptional mechanisms to prevent the expression of $\mathrm{p} 16^{\text {Ink4a }}$ and $\mathrm{p} 19^{\text {Arf }}$ in stem cells. Such pathways are temporally regulated by changes in let-7b and Hmga2 expression to allow $\mathrm{p} 16^{\text {Ink4a }}$ and $\mathrm{p} 19^{\text {Arf }}$ expression in aging stem cells (Fig. 4). In this way, self-renewal mech- anisms can maintain stem cells throughout life while augmenting tumor suppression in aging stem cells.

p16 $6^{\text {Ink4a }}$ and $\mathrm{p} 19^{\text {Arf }}$ may be broadly important to diseases of aging beyond their function in stem cells. Several genome-wide association studies of large human populations revealed that polymorphisms at the $p 16^{\operatorname{Ink} 4 a} / p 19^{A r f}$ locus (chromosome 9p21) are associated with frailty (Melzer et al. 2007), atherosclerotic heart disease (Helgadottir et al. 2007, 2008; McPherson et al. 2007; Wellcome Trust Case Control Consortium 2007), and type-2 diabetes (Saxena et al. 2007; Wellcome Trust Case Control Consortium 2007; Zeggini et al. 2007). Although these studies do not pinpoint the polymorphisms that affect the risks of age-related diseases, there are only four genes in the vicinity of the mapped polymorphisms: p16 $6^{\text {Ink4a }}, p 19^{A r f}, p 15^{\text {Ink } 4 b}$, and ANRIL (a noncoding RNA) (Sharpless and DePinho 2007). p16 $6^{\text {Ink4a }}$ expression increases with age in pancreatic $\beta$ cells, and $p 16^{\text {Ink4a }}$ deficiency increases $\beta$-cell regenerative capacity (Krishnamurthy et al. 2006), providing a mechanism by which polymorphisms that affect $\mathrm{p} 16^{\text {Ink4a }}$ expression or activity might affect risk for type- 2 diabetes. It remains unclear whether these polymorphisms influence the risk of frailty and heart disease through their effects on tissue regenerative capacity or by mechanisms that are completely independent of stem/progenitor cells.

p $16^{\text {ink4a }}$ may not be the only tumor suppressor that influences stem cell self-renewal, tissue regenerative capacity, age-related disease, and cancer. p53 is a well-known tumor suppressor that is frequently inactivated in human cancers. A polymorphism in p53 increases longevity and survival after cancer diagnosis in humans (Orsted et al. 2007). Overexpression of short isoforms of p53 in mice leads to early-onset aging phenotypes and decreased longevity (Tyner et al. 2002; Maier et al. 2004). These results raise the possibility that polymorphisms that increase p53 activity decrease cancer incidence but promote aging, whereas polymorphisms that decrease p53 activity increase cancer incidence but slow aging. However, bacterial artificial chromosome transgenic mice that bear a third copy of the $p 53$ locus or the $p 15^{\text {Ink } 4 b}$ / $p 16^{\text {Ink } 4 a} / p 19^{A r f}$ locus show a decreased cancer incidence but normal longevity and normal onset of aging phenotypes (Garcia-Cao et al. 2002; Matheu et al. 2004). Complicating matters further, mice that bear a third copy of the $p 53$ locus and a third copy of the $p 15^{\text {Ink } 4 b} / p 16^{\text {Ink4a }}$ $p 19^{A r f}$ locus show increased longevity and delayed aging in a manner that cannot be explained by their reduced incidence of cancer (Matheu et al. 2007). These results suggest that the effects of $p 53$ and $p 15^{\text {Ink } 4 b} / p 16^{\text {Ink } 4 a} / p 19^{A r f}$ expression on aging are context and dosage dependent and likely reflect a complex mix of mechanisms.

\section{Insights from Other Systems}

A series of studies conducted on aging muscle have shown that the function of aging stem cells is also affected by environmental change. Muscle satellite cells poorly regenerate injured muscles in aging animals, partly due to reduced Notch signaling in aging satellite cells (Conboy 

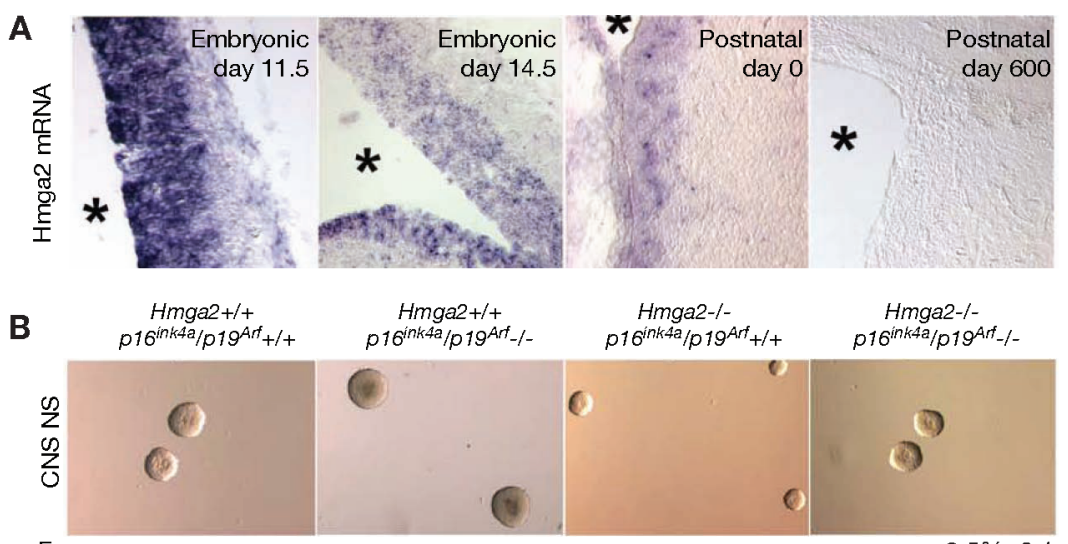

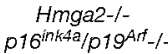
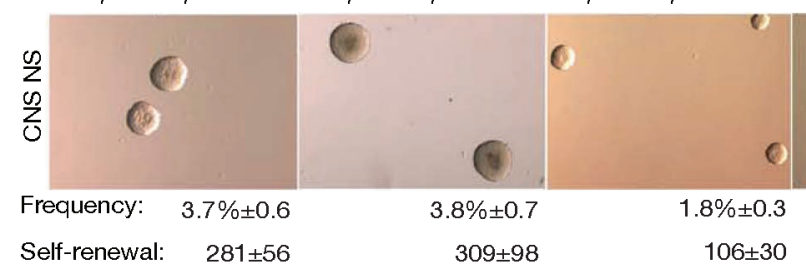

$309_{ \pm 98}$

$1.8 \% \pm 0.3$

$106 \pm 30$

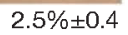

C
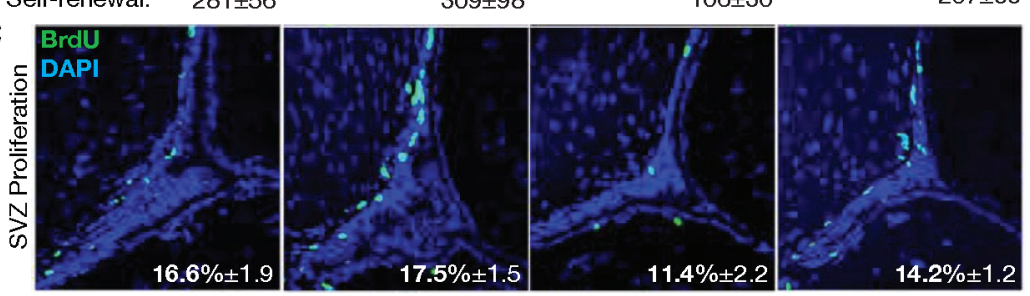

D
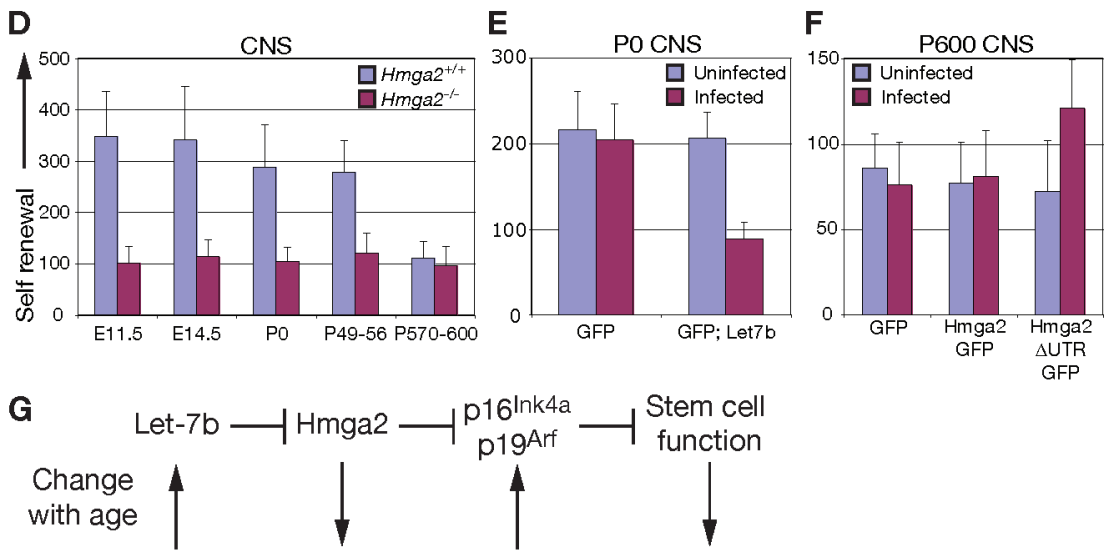

Figure 3. Hmga2 and let- $7 b$ regulate $16^{\text {Ink4a }} / \mathrm{p} 19^{\text {Arf }}$ expression and stem cell self-renewal in an age-related manner. (A) Hmga2 is expressed by undifferentiated cells in the ventricular/subventricular zone and expression declines with age. Expression can no longer be detected in the subventricular zone of old adult mice. Asterisk indicates the ventricle. (B) Hmga2 deficiency reduced the frequency (percentage of cells that formed stem cell colonies in culture) and self-renewal potential (number of secondary stem cell colonies generated per primary colony upon subcloning) of stem cells cultured from the fetal and young adult brain. $p 16^{\operatorname{Ink} 4 a} / p 19^{4 n f}$ deficiency partially rescued these defects. Statistics reflect mean \pm standard. (C) Hmga2 deficiency reduced the rate of proliferation within the subventricular zone of young adult mice, but $p 16^{\text {Ink4a }} / p 19^{4 r f}$ deficiency partially rescued this defect. Numbers indicate the percentage of subventricular zone cells (mean \pm S.D.) that incorporate a pulse of BrdU in vivo. (D) Hmga2 deficiency reduced the self-renewal potential of stem cells cultured from the fetal and young adult brain but did not affect the self-renewal potential of stem cells from the old adult brain. $(E$ ) Overexpression of let-7b, but not GFP control, reduced the self-renewal of neural stem cells. (F) Deletion of the Hmga2 3'UTR (eliminating let-7-binding sites) was required to increase Hmga2 protein levels in old neural stem cells (data not shown). This let-7-insensitive form of Hmga2, but not wild-type Hmga2, significantly increased the self-renewal of neural stem cells from old mice. (G) Schematic of the mechanism by which changes in let-7b and Hmga2 expression during aging regulate stem cell function. (Reprinted from Nishino et al. 2008. [C Cell Press].)

et al. 2003). However, when the circulatory systems of old and young mice are parabiotically fused, Notch signaling and muscle regeneration in the old mice are restored to young levels (Conboy et al. 2005). This demonstrates that age-related changes in stem cells are governed by both local and systemic environmental changes. Further mechanistic insights into these changes were provided by the observation that Wnt signaling is elevated in aging mice and that this contributes to the reduced regenerative capacity (Brack et al. 2007). This finding was supported by the discovery that Klotho-deficient mice, which exhibit elevated Wnt signaling and premature aging, lack a secreted Wnt antagonist (Liu et al. 2007). Other environmental changes also occur during aging, such as increasing TGF- $\beta$ signaling. The increase in TGF- $\beta$ signaling leads to increased expression of 


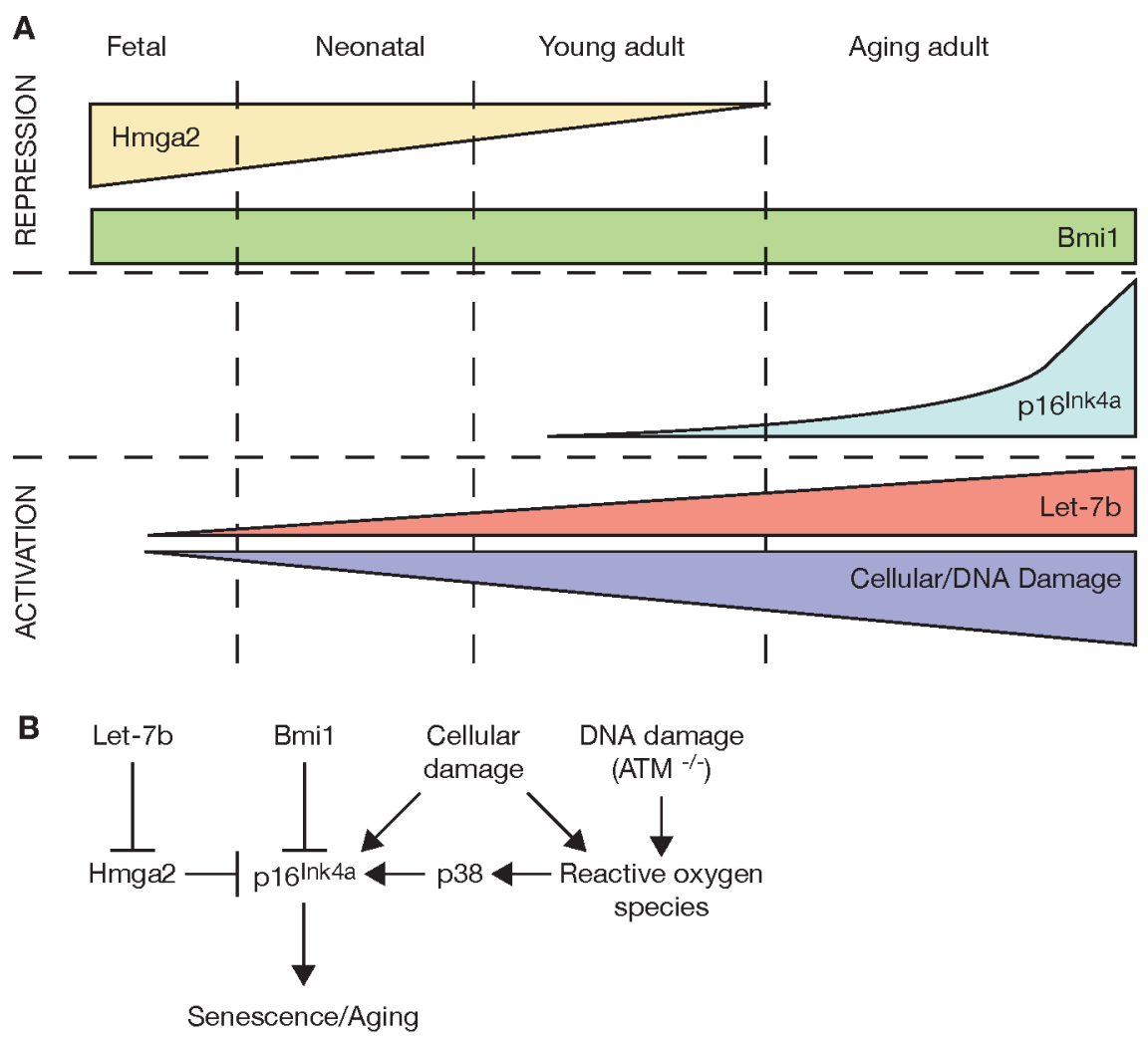

Figure 4. Age-related changes in $\mathrm{p} 16^{\mathrm{Ink} 4 \mathrm{a}}$ regulation. $(A)$ Schematic of genes and processes that affect $\mathrm{p} 16^{\mathrm{Ink} 4 \mathrm{a}}$ expression during aging. $(B)$ A summary of $\mathrm{p} 16^{\text {Ink4a }}$ regulatory mechanisms within stem cells.

cyclin-dependent kinase inhibitors, including $\mathrm{p} 16^{\mathrm{Ink} 4 \mathrm{a}}$ (Carlson et al. 2008). This provides a mechanism by which environmental changes that occur during aging can regulate cell-intrinsic factors identified in prior studies.

\section{PERSPECTIVE}

For a mammal to survive, stem cells must maintain their ability to self-renew throughout life. Tissue growth and regeneration demands change dramatically over the course of an animal's life, and the genetic programs regulating stem cell self-renewal change accordingly. Stem cells from embryonic, fetal, young adult, and old adult stages use somewhat different mechanisms to regulate their self-renewal (see Table 1).

Many key mechanisms that regulate stem cell selfrenewal do not generically regulate all progenitor proliferation. Deletion of Bmi-1, Hmga2, or $p 16^{\text {Ink4a }}$ leads to self-renewal phenotypes in multipotent stem cells without affecting the proliferation of many restricted progenitors (Molofsky et al. 2003, 2006; Nishino et al. 2008). Sox17 is absolutely required for the maintenance of fetal HSCs but is not expressed by most restricted hematopoietic progenitors in the fetal liver (Kim et al. 2007). These results demonstrate that the self-renewal of stem cells is mechanistically distinct from the proliferation of many restricted progenitors. Nonetheless, this is not a black and white difference, because some restricted progenitors, such as lym- phocytes and cerebellar granule precursor cells, also depend on Bmi-1 (van der Lugt et al. 1994; Leung et al. 2004). This suggests that some restricted progenitors use self-renewal mechanisms that are similar to those of stem cells.

A fundamental requirement for the maintenance of stem cells throughout life is the repression of $\mathrm{p} 16^{\text {ink4a }}$ and p19 Arf tumor suppressors. This is often accomplished by stage-specific transcriptional regulatory mechanisms, such as Hmga2 and Bmi-1. The regulation of $\mathrm{p} 16^{\text {ink4a }}$ and p19 Arf in a stage-specific manner confers the capacity for dynamic regulation. As the risk of cancer increases during aging, these genes are induced, reducing stem cell frequency and function in multiple tissues. Stem cell selfrenewal is regulated by networks of proto-oncogenes and tumor suppressors that balance the need to maintain stem cells throughout life with the need to avoid neoplastic transformation. An important, although difficult, future question is whether the mechanisms that regulate stem cell aging also control life span and whether stem cell aging influences longevity.

The age-related changes in stem cell self-renewal programs are also likely to mean that different mutations are required for carcinogenesis at different stages of life. Cancers consistently arise from mutations that inappropriately activate self-renewal pathways (Reya et al. 2001; Pardal et al. 2003). Because self-renewal pathways change with age, we hypothesize that different mutations 
are required for neoplastic transformation at different ages, irrespective of whether cancers arise from stem cells or restricted progenitors/differentiated cells. This hypothesis remains to be tested directly, but it provides one explanation for the observation that adult cancers often have different mutation spectrums as compared to the childhood versions of the same cancers (Downing and Shannon 2002). A more sophisticated understanding of self-renewal mechanisms and how they change with age could provide new anticancer strategies.

\section{ACKNOWLEDGMENTS}

This work was supported by the Howard Hughes Medical Institute and the National Institutes of Health (1 RO1 AG024945-01). B.P.L was supported by an American Heart Association postdoctoral fellowship (0725726Z) and a Cancer Research Institute postdoctoral fellowship. We thank Ivan Maillard and Jeff Magee for reviewing the manuscript.

\section{REFERENCES}

Akala, O.O., Park, I.K., Qian, D., Pihalja, M., Becker, M.W., and Clarke, M.F. 2008. Long-term haematopoietic reconstitution by $\operatorname{Trp} 53^{--} p 16^{\text {Ink } 4 a-1} p 19^{4 r f-/}$ multipotent progenitors. Nature 453: 228-232.

Alonso, M., Viollet, C., Gabellec, M.M., Meas-Yedid, V., Olivo-Marin, J.C., and Lledo, P.M. 2006. Olfactory discrimination learning increases the survival of adult-born neurons in the olfactory bulb. J. Neurosci. 26: 10508-10513.

Anthony, T.E., Klein, C., Fishell, G., and Heintz, N. 2004 Radial glia serve as neuronal progenitors in all regions of the central nervous system. Neuron 41: 881-890.

Arai, F., Hirao, A., Ohmura, M., Sato, H., Matsuoka, S., Takubo, K., Ito, K., Koh, G.Y., and Suda, T. 2004. Tie2/angiopoietin1 signaling regulates hematopoietic stem cell quiescence in the bone marrow niche. Cell 118: 149-161.

Avilion, A.A., Nicolis, S.K., Pevny, L.H., Perez, L., Vivian, N., and Lovell-Badge, R. 2003. Multipotent cell lineages in early mouse development depend on SOX2 function. Genes Dev. 17: $126-140$

Azcoitia, V., Aracil, M., Martinez, A.C., and Torres, M. 2005. The homeodomain protein Meis1 is essential for definitive hematopoiesis and vascular patterning in the mouse embryo. Dev. Biol. 280: 307-320.

Bixby, S., Kruger, G.M., Mosher, J.T., Joseph, N.M., and Morrison, S.J. 2002. Cell-intrinsic differences between stem cells from different regions of the peripheral nervous system regulate the generation of neural diversity. Neuron 35: 643-656.

Bowie, M.B., McKnight, K.D., Kent, D.G., McCaffrey, L., Hoodless, P.A., and Eaves, C.J. 2006. Hematopoietic stem cells proliferate until after birth and show a reversible phasespecific engraftment defect. J. Clin. Invest. 116: 2808-2816.

Bowie, M.B., Kent, D.G., Dykstra, B., McKnight, K.D., McCaffrey, L., Hoodless, P.A., and Eaves, C.J. 2007. Identification of a new intrinsically timed developmental checkpoint that reprograms key hematopoietic stem cell properties. Proc. Natl. Acad. Sci. 104: 5878-5882.

Boyer, L.A., Lee, T.I., Cole, M.F., Johnstone, S.E., Levine, S.S., Zucker, J.P., Guenther, M.G., Kumar, R.M., Murray, H.L., Jenner, R.G., et al. 2005. Core transcriptional regulatory circuitry in human embryonic stem cells. Cell 122: 947-956.

Brack, A.S., Conboy, M.J., Roy, S., Lee, M., Kuo, C.J., Keller, C., and Rando, T.A. 2007. Increased Wnt signaling during aging alters muscle stem cell fate and increases fibrosis. Science 317: 807-810.

Bruggeman, S.W., Valk-Lingbeek, M.E., van der Stoop, P.P.,
Jacobs, J.J., Kieboom, K., Tanger, E., Hulsman, D., Leung, C., Arsenijevic, Y., Marino, S., and van Lohuizen, M. 2005. Ink $4 a$ and Arf differentially affect cell proliferation and neural stem cell self-renewal in Bmil-deficient mice. Genes Dev. 19: 1438-1443.

Buaas, F.W., Kirsh, A.L., Sharma, M., McLean, D.J., Morris, J.L., Griswold, M.D., de Rooij, D.G., and Braun, R.E. 2004. $\mathrm{Plzf}$ is required in adult male germ cells for stem cell selfrenewal. Nat. Genet. 36: 647-652.

Bylund, M., Andersson, E., Novitch, B.G., and Muhr, J. 2003. Vertebrate neurogenesis is counteracted by Sox1-3 activity. Nat. Neurosci. 6: 1162-1168.

Carlson, M.E., Hsu, M., and Conboy, I.M. 2008. Imbalance between pSmad 3 and Notch induces CDK inhibitors in old muscle stem cells. Nature 454: 528-532.

Chambers, I., Colby, D., Robertson, M., Nichols, J., Lee, S., Tweedie, S., and Smith, A. 2003. Functional expression cloning of Nanog, a pluripotency sustaining factor in embryonic stem cells. Cell 113: 643-655.

Chambers, I., Silva, J., Colby, D., Nichols, J., Nijmeijer, B., Robertson, M., Vrana, J., Jones, K., Grotewold, L., and Smith, A. 2007. Nanog safeguards pluripotency and mediates germline development. Nature 450: 1230-1234.

Chen, J., Astle, C.M., and Harrison, D.E. 2000. Genetic regulation of primitive hematopoietic stem cell senescence. Exp. Hematol. 28: 442-450.

Chenn, A. and McConnell, S.K. 1995. Cleavage orientation and the asymmetric inheritance of Notch1 immunoreactivity in mammalian neurogenesis. Cell 82: 631-641.

Cheshier, S., Morrison, S.J., Liao, X., and Weissman, I.L. 1999. In vivo proliferation and cell cycle kinetics of long-term selfrenewing hematopoietic stem cells. Proc. Natl. Acad. Sci. 96: $3120-3125$.

Conboy, I.M., Conboy, M.J., Smythe, G.M., and Rando, T.A. 2003. Notch-mediated restoration of regenerative potential to aged muscle. Science 302: 1575-1577.

Conboy, I.M., Conboy, M.J., Wagers, A.J., Girma, E.R., Weissman, I.L., and Rando, T.A. 2005. Rejuvenation of aged progenitor cells by exposure to a young systemic environment. Nature 433: 760-764.

Costoya, J.A., Hobbs, R.M., Barna, M., Cattoretti, G., Manova, K., Sukhwani, M., Orwig, K.E., Wolgemuth, D.J., and Pandolfi, P.P. 2004. Essential role of Plzf in maintenance of spermatogonial stem cells. Nat. Genet. 36: 653-659.

Curtis, M.A., Kam, M., Nannmark, U., Anderson, M.F., Axell, M.Z., Wikkelso, C., Holtas, S., van Roon-Mom, W.M., BjorkEriksson, T., Nordborg, C., et al. 2007. Human neuroblasts migrate to the olfactory bulb via a lateral ventricular extension. Science 315: 1243-1249.

Dani, C., Chambers, I., Johnstone, S., Robertson, M., Ebrahimi, B., Saito, M., Taga, T., Li, M., Burdon, T., Nichols, J., and Smith, A. 1998. Paracrine induction of stem cell renewal by LIF-deficient cells: A new ES cell regulatory pathway. Dev. Biol. 203: 149-162.

de Haan, G. and Van Zant, G. 1999. Dynamic changes in mouse hematopoietic stem cell numbers during aging. Blood 93: 3294-3301.

de Haan, G., Nijhof, W., and Van Zant, G. 1997. Mouse straindependent changes in frequency and proliferation of hematopoietic stem cells during aging: Correlation between lifespan and cycling activity. Blood 89: 1543-1550.

Dejosez, M., Krumenacker, J.S., Zitur, L.J., Passeri, M., Chu, L.F., Songyang, Z., Thomson, J.A., and Zwaka, T.P. 2008. Ronin is essential for embryogenesis and the pluripotency of mouse embryonic stem cells. Cell 133: 1162-1174.

Desai, A.R. and McConnell, S.K. 2000. Progressive restriction in fate potential by neural progenitors during cerebral cortical development. Development 127: 2863-2872.

Doetsch, F., Caille, I., Lim, D.A., Garcia-Verdugo, J.M., and Alvarez-Buylla, A. 1999. Subventricular zone astrocytes are neural stem cells in the adult mammalian brain. Cell 97: 703-716.

Downing, J.R. and Shannon, K.M. 2002. Acute leukemia: A pediatric perspective. Cancer Cell 2: 437-445. 
Enwere, E., Shingo, T., Gregg, C., Fujikawa, H., Ohta, S., and Weiss, S. 2004. Aging results in reduced epidermal growth factor receptor signaling, diminished olfactory neurogenesis, and deficits in fine olfactory discrimination. J. Neurosci. 24: 8354-8365.

Eriksson, P.S., Perfilieva, E., Bjork-Eriksson, T., Alborn, A.-M., Nordborg, C., Peterson, D.A., and Gage, F.H. 1998. Neurogenesis in the adult human hippocampus. Nat. Med. 4: 13131317.

Falender, A.E., Freiman, R.N., Geles, K.G., Lo, K.C., Hwang, K., Lamb, D.J., Morris, P.L., Tjian, R., and Richards, J.S. 2005. Maintenance of spermatogenesis requires TAF4b, a gonad-specific subunit of TFIID. Genes Dev. 19: 794-803.

Ferri, A.L., Cavallaro, M., Braida, D., Di Cristofano, A., Canta, A., Vezzani, A., Ottolenghi, S., Pandolfi, P.P., Sala, M., DeBiasi, S., and Nicolis, S.K. 2004. Sox2 deficiency causes neurodegeneration and impaired neurogenesis in the adult mouse brain. Development 131: 3805-3819.

Frantz, G.D. and McConnell, S.K. 1996. Restriction of late cerebral cortical progenitors to an upper-layer fate. Neuron 17: $55-61$.

Fujita, J., Crane, A.M., Souza, M.K., Dejosez, M., Kyba, M., Flavell, R.A., Thomson, J.A., and Zwaka, T.P. 2008. Caspase activity mediates the differentiation of embryonic stem cells. Cell Stem Cell 2: 595-601.

Galan-Caridad, J.M., Harel, S., Arenzana, T.L., Hou, Z.E., Doetsch, F.K., Mirny, L.A., and Reizis, B. 2007. Zfx controls the self-renewal of embryonic and hematopoietic stem cells. Cell 129: 345-357.

Garcia, A.D., Doan, N.B., Imura, T., Bush, T.G., and Sofroniew, M.V. 2004. GFAP-expressing progenitors are the principal source of constitutive neurogenesis in adult mouse forebrain. Nat. Neurosci. 7: 1233-1241.

Garcia-Cao, I., Garcia-Cao, M., Martin-Caballero, J., Criado, L.M., Klatt, P., Flores, J.M., Weill, J.C., Blasco, M.A., and Serrano, M. 2002. "Super p53" mice exhibit enhanced DNA damage response, are tumor resistant and age normally. EMBO J. 21: 6225-6235.

Geiger, H. and Van Zant, G. 2002. The aging of lymphohematopoietic stem cells. Nat. Immunol. 3: 329-333.

Graham, V., Khudyakov, J., Ellis, P., and Pevny, L. 2003. SOX2 functions to maintain neural progenitor identity. Neuron 39: 749-765.

Guarente, L. 2008. Mitochondria-A nexus for aging, calorie restriction, and sirtuins? Cell 132: 171-176.

Hanashima, C., Li, S.C., Shen, L., Lai, E., and Fishell, G. 2004. Foxg1 suppresses early cortical cell fate. Science 303: 56-59.

Harrison, D.E. and Astle, C.M. 1982. Loss of stem cell repopulating ability upon transplantation: Effects of donor age, cell number, and transplantation procedure. J. Exp. Med. 156: $1767-1779$.

Haubensak, W., Attardo, A., Denk, W., and Huttner, W.B. 2004. Neurons arise in the basal neuroepithelium of the early mammalian telencephalon: A major site of neurogenesis. Proc. Natl. Acad. Sci. 101: 3196-3201.

Hayakawa, K., Hardy, R.R., Hertzenberg, L.A., and Herzenberg, L.A. 1985. Progenitors for Ly-1 B cells are distinct from progenitors for other B cells. J. Exp. Med. 161: 1554-1568.

Helgadottir, A., Thorleifsson, G., Magnusson, K.P., Gretarsdottir, S., Steinthorsdottir, V., Manolescu, A., Jones, G.T., Rinkel, G.J., Blankensteijn, J.D., Ronkainen, A., et al. 2008. The same sequence variant on 9p21 associates with myocardial infarction, abdominal aortic aneurysm and intracranial aneurysm. Nat. Genet. 40: 217-224.

Helgadottir, A., Thorleifsson, G., Manolescu, A., Gretarsdottir, S., Blondal, T., Jonasdottir, A., Jonasdottir, A., Sigurdsson, A., Baker, A., Palsson, A., et al. 2007. A common variant on chromosome 9p21 affects the risk of myocardial infarction. Science 316: 1491-1493.

Hisa, T., Spence, S.E., Rachel, R.A., Fujita, M., Nakamura, T., Ward, J.M., Devor-Henneman, D.E., Saiki, Y., Kutsuna, H., Tessarollo, L., Jenkins, N.A., and Copeland, N.G. 2004. Hematopoietic, angiogenic and eye defects in Meis 1 mutant animals. EMBO J. 23: 450-459.
Hock, H., Hamblen, M.J., Rooke, H.M., Schindler, J.W., Saleque, S., Fujiwara, Y., and Orkin, S.H. 2004a. Gfi-1 restricts proliferation and preserves functional integrity of haematopoietic stem cells. Nature 431: 1002-1007.

Hock, H., Meade, E., Medeiros, S., Schindler, J.W., Valk, P.J., Fujiwara, Y., and Orkin, S.H. 2004b. Tel/Etv6 is an essential and selective regulator of adult hematopoietic stem cell survival. Genes Dev. 18: 2336-2341.

Ikuta, K., Kina, T., Macneil, I., Uchida, N., Peault, B., Chien, Y.H., and Weissman, I.L. 1990. A developmental switch in thymic lymphocyte maturation potential occurs at the level of hematopoietic stem cells. Cell 62: 863-874.

Imura, T., Kornblum, H.I., and Sofroniew, M.V. 2003. The predominant neural stem cell isolated from postnatal and adult forebrain but not early embryonic forebrain expresses GFAP. J. Neurosci. 23: 2824-2832.

Ito, K., Hirao, A., Arai, F., Takubo, K., Matsuoka, S., Miyamoto, K., Ohmura, M., Naka, K., Hosokawa, K., Ikeda, Y., and Suda, T. 2006. Reactive oxygen species act through p38 MAPK to limit the lifespan of hematopoietic stem cells. Nat. Med. 12: 446-451.

Ivanova, N., Dobrin, R., Lu, R., Kotenko, I., Levorse, J., DeCoste, C., Schafer, X., Lun, Y., and Lemischka, I.R. 2006. Dissecting self-renewal in stem cells with RNA interference. Nature 442: 533-538.

Iwasaki, H., Somoza, C., Shigematsu, H., Duprez, E.A., IwasakiArai, J., Mizuno, S., Arinobu, Y., Geary, K., Zhang, P., Dayaram, T., et al. 2005. Distinctive and indispensable roles of PU.1 in maintenance of hematopoietic stem cells and their differentiation. Blood 106: 1590-1600.

Jacobs, J.J., Kieboom, K., Marino, S., DePinho, R.A., and van Lohuizen, M. 1999. The oncogene and Polycomb-group gene bmi-1 regulates cell proliferation and senescence through the ink4a locus. Nature 397: 164-168.

Jaenisch, R. and Young, R. 2008. Stem cells, the molecular circuitry of pluripotency and nuclear reprogramming. Cell 132: $567-582$.

Janzen, V., Forkert, R., Fleming, H.E., Saito, Y., Waring, M.T., Dombkowski, D.M., Cheng, T., DePinho, R.A., Sharpless, N.E., and Scadden, D.T. 2006. Stem-cell ageing modified by the cyclin-dependent kinase inhibitor $\mathrm{p} 16^{\mathrm{INK} 4 \mathrm{a}}$. Nature 443: 421-426.

Janzen, V., Fleming, H.E., Riedt, T., Karlsson, G., Riese, M.J., Lo Celso, C., Reynolds, G., Milne, C.D., Paige, C.J., Karlsson, S., et al. 2008. Hematopoietic stem cell responsiveness to exogenous signals is limited by caspase-3. Cell Stem Cell 2: 584-594.

Johnson, M.H. and McConnell, J.M. 2004. Lineage allocation and cell polarity during mouse embryogenesis. Semin. Cell Dev. Biol. 15: 583-597.

Kantor, A.B., Stall, A.M., Adams, S., Herzenberg, L.A., and Herzenberg, L.A. 1992. Differential development of progenitor activity for three B-cell lineages. Proc. Natl. Acad. Sci. 89: 3320-3324.

Kiel, M.J., He, S., Ashkenazi, R., Gentry, S.N., Teta, M., Kushner, J.A., Jackson, T.L., and Morrison, S.J. 2007. Haematopoietic stem cells do not asymmetrically segregate chromosomes or retain BrdU. Nature 449: 238-242.

Kim, H.G., de Guzman, C.G., Swindle, C.S., Cotta, C.V., Gartland, L., Scott, E.W., and Klug, C.A. 2004a. The ETS family transcription factor PU.1 is necessary for the maintenance of fetal liver hematopoietic stem cells. Blood 104: 3894-3900.

Kim, I., Saunders, T.L., and Morrison, S.J. 2007. Sox17 dependence distinguishes the transcriptional regulation of fetal from adult hematopoietic stem cells. Cell 130: 470-483.

Kim, J.Y., Sawada, A., Tokimasa, S., Endo, H., Ozono, K., Hara, J., and Takihara, Y. 2004b. Defective long-term repopulating ability in hematopoietic stem cells lacking the Polycombgroup gene rae28. Eur. J. Haematol. 73: 75-84.

Kirito, K., Fox, N., and Kaushansky, K. 2004. Thrombopoietin induces HOXA9 nuclear transport in immature hematopoietic cells: Potential mechanism by which the hormone favorably affects hematopoietic stem cells. Mol. Cell. Biol. 24: 67516762. 
Krishnamurthy, J., Ramsey, M.R., Ligon, K.L., Torrice, C., Koh, A., Bonner-Weir, S., and Sharpless, N.E. 2006. p16 $6^{\mathrm{INK} 4 \mathrm{a}}$ induces an age-dependent decline in islet regenerative potential. Nature 443: 453-457.

Krishnamurthy, J., Torrice, C., Ramsey, M.R., Kovalev, G.I., Al-Regaiey, K., Su, L., and Sharpless, N.E. 2004. Ink4a/Arf expression is a biomarker of aging. J. Clin. Invest. 114: 12991307.

Kruger, G.M., Mosher, J.T., Bixby, S., Joseph, N., Iwashita, T., and Morrison, S.J. 2002. Neural crest stem cells persist in the adult gut but undergo changes in self-renewal, neuronal subtype potential, and factor responsiveness. Neuron 35: 657-669.

Kuhn, H.G., Dickinson-Anson, H., and Gage, F.H. 1996 Neurogenesis in the dentate gyrus of the adult rat: Age-related decrease of neuronal progenitor proliferation. J. Neurosci. 16: 2027-2033.

Kuo, C.T., Mirzadeh, Z., Soriano-Navarro, M., Rasin, M., Wang, D., Shen, J., Sestan, N., Garcia-Verdugo, J., AlvarezBuylla, A., Jan, L.Y., and Jan, Y.N. 2006. Postnatal deletion of Numb/Numblike reveals repair and remodeling capacity in the subventricular neurogenic niche. Cell 127: 1253-1264.

Lechler, T. and Fuchs, E. 2005. Asymmetric cell divisions promote stratification and differentiation of mammalian skin. Nature 437: 275-280.

Lee, Y.S. and Dutta, A. 2007. The tumor suppressor microRNA let-7 represses the HMGA2 oncogene. Genes Dev. 21: 10251030.

Lengner, C.J., Camargo, F.D., Hochedlinger, K., Welstead, G.G., Zaidi, S., Gokhale, S., Scholer, H.R., Tomilin, A., and Jaenisch, R. 2007. Oct4 expression is not required for mouse somatic stem cell self-renewal. Cell Stem Cell 1: 403-415.

Lessard, J. and Sauvageau, G. 2003. Bmi-1 determines the proliferative capacity of normal and leukaemic stem cells. Nature 423: 255-260.

Leung, C., Lingbeek, M., Shakhova, O., Liu, J., Tanger, E., Saremaslani, P., van Lohuizen, M., and Marino, S. 2004. Bmil is essential for cerebellar development and is overexpressed in human medulloblastomas. Nature 428: 337-341.

Li, M., Sendtner, M., and Smith, A. 1995. Essential function of LIF receptor in motor neurons. Nature 378: 724-727.

Liang, Y., Van Zant, G., and Szilvassy, S.J. 2005. Effects of aging on the homing and engraftment of murine hematopoietic stem and progenitor cells. Blood 106: 1479-1487.

Liu, H., Fergusson, M.M., Castilho, R.M., Liu, J., Cao, L., Chen, J., Malide, D., Rovira, I.I., Schimel, D., Kuo, C.J., et al. 2007. Augmented Wnt signaling in a mammalian model of accelerated aging. Science 317: 803-806.

Loh, Y.H., Wu, Q., Chew, J.L., Vega, V.B., Zhang, W., Chen, X., Bourque, G., George, J., Leong, B., Liu, J., et al. 2006. The Oct4 and Nanog transcription network regulates pluripotency in mouse embryonic stem cells. Nat. Genet. 38: 431-440.

Lowe, S.W. and Sherr, C.J. 2003. Tumor suppression by Ink4aArf: Progress and puzzles. Curr. Opin. Genet. Dev. 13: 77-83.

Magavi, S.S., Mitchell, B.D., Szentirmai, O., Carter, B.S., and Macklis, J.D. 2005. Adult-born and preexisting olfactory granule neurons undergo distinct experience-dependent modifications of their olfactory responses in vivo. J. Neurosci. 25: 10729-10739.

Maier, B., Gluba, W., Bernier, B., Turner, T., Mohammad, K., Guise, T., Sutherland, A., Thorner, M., and Scrable, H. 2004. Modulation of mammalian life span by the short isoform of p53. Genes Dev. 18: 306-319.

Maslov, A.Y., Barone, T.A., Plunkett, R.J., and Pruitt, S.C. 2004. Neural stem cell detection, characterization, and agerelated changes in the subventricular zone of mice. $J$. Neurosci. 24: 1726-1733.

Masui, S., Nakatake, Y., Toyooka, Y., Shimosato, D., Yagi, R., Takahashi, K., Okochi, H., Okuda, A., Matoba, R., Sharov, A.A., Ko, M.S., and Niwa, H. 2007. Pluripotency governed by Sox 2 via regulation of Oct $3 / 4$ expression in mouse embryonic stem cells. Nat. Cell Biol. 9: 625-635.

Matheu, A., Pantoja, C., Efeyan, A., Criado, L.M., MartinCaballero, J., Flores, J.M., Klatt, P., and Serrano, M. 2004. Increased gene dosage of Ink4a/Arf results in cancer resis- tance and normal aging. Genes Dev. 18: 2736-2746.

Matheu, A., Maraver, A., Klatt, P., Flores, I., Garcia-Cao, I., Borras, C., Flores, J.M., Viña, J., Blasco, M.A., and Serrano, M. 2007. Delayed ageing through damage protection by the Arf/p53 pathway. Nature 448: 375-379.

Mayr, C., Hemann, M.T., and Bartel, D.P. 2007. Disrupting the pairing between let-7 and Hmga2 enhances oncogenic transformation. Science 315: 1576-1579.

McMahon, K.A., Hiew, S.Y., Hadjur, S., Veiga-Fernandes, H., Menzel, U., Price, A.J., Kioussis, D., Williams, O., and Brady, H.J. 2007. Mll has a critical role in fetal and adult hematopoietic stem cell self-renewal. Cell Stem Cell 1: 338-345.

McPherson, R., Pertsemlidis, A., Kavaslar, N., Stewart, A., Roberts, R., Cox, D.R., Hinds, D.A., Pennacchio, L.A., Tybjaerg-Hansen, A., Folsom, A.R., et al. 2007. A common allele on chromosome 9 associated with coronary heart disease. Science 316: 1488-1491.

Melzer, D., Frayling, T.M., Murray, A., Hurst, A.J., Harries, L.W., Song, H., Khaw, K., Luben, R., Surtees, P.G., Bandinelli, S.S., et al. 2007. A common variant of the $\mathrm{p} 16^{\mathrm{INK} 4 \mathrm{a}}$ genetic region is associated with physical function in older people. Mech. Ageing Dev. 128: 370-377.

Merkle, F.T., Tramontin, A.D., Garcia-Verdugo, J.M., and Alvarez-Buylla, A. 2004. Radial glia give rise to adult neural stem cells in the subventricular zone. Proc. Natl. Acad. Sci. 101: 17528-17532.

Mitsui, K., Tokuzawa, Y., Itoh, H., Segawa, K., Murakami, M., Takahashi, K., Maruyama, M., Maeda, M., and Yamanaka, S. 2003. The homeoprotein Nanog is required for maintenance of pluripotency in mouse epiblast and ES cells. Cell 113: 631-642.

Miyamoto, K., Araki, K.Y., Naka, K., Arai, F., Takubo, K., Yamazaki, S., Matsuoka, S., Miyamoto, T., Ito, K., Ohmura, M., et al. 2007. Foxo3a is essential for maintenance of the hematopoietic stem cell pool. Cell Stem Cell 1: 101-112.

Miyata, T., Kawaguchi, A., Saito, K., Kuramochi, H., and Ogawa, M. 2002. Visualization of cell cycling by an improvement in slice culture methods. J. Neurosci. Res. 69: 861-868.

Miyawaki, T., Uemura, A., Dezawa, M., Yu, R.T., Ide, C., Nishikawa, S., Honda, Y., Tanabe, Y., and Tanabe, T. 2004. Tlx, an orphan nuclear receptor, regulates cell numbers and astrocyte development in the developing retina. J. Neurosci. 24: 8124-8134.

Molofsky, A.V., Pardal, R., and Morrison, S.J. 2004. Diverse mechanisms regulate stem cell self-renewal. Curr. Opin. Cell Biol. 16: 700-707.

Molofsky, A.V., He, S., Bydon, M., Morrison, S.J., and Pardal, R. 2005. Bmi-1 promotes neural stem cell self-renewal and neural development but not mouse growth and survival by repressing the $\mathrm{p} 16^{\text {Ink4a }}$ and $\mathrm{p} 19^{\text {Arf }}$ senescence pathways. Genes Dev. 19: 1432-1437.

Molofsky, A.V., Pardal, R., Iwashita, T., Park, I.K., Clarke, M.F., and Morrison, S.J. 2003. Bmi-1 dependence distinguishes neural stem cell self-renewal from progenitor proliferation. Nature 425: 962-967.

Molofsky, A.V., Slutsky, S.G., Joseph, N.M., He, S., Pardal, R., Krishnamurthy, J., Sharpless, N.E., and Morrison, S.J. 2006. Increasing $p 16^{I N K 4 a}$ expression decreases forebrain progenitors and neurogenesis during ageing. Nature 443: 448-452.

Morrison, S.J. and Kimble, J. 2006. Asymmetric and symmetric stem-cell divisions in development and cancer. Nature 441: 1068-1074.

Morrison, S.J., Hemmati, H.D., Wandycz, A.M., and Weissman, I.L. 1995. The purification and characterization of fetal liver hematopoietic stem cells. Proc. Natl. Acad. Sci. 92: 1030210306

Morrison, S.J., White, P.M., Zock, C., and Anderson, D.J. 1999. Prospective identification, isolation by flow cytometry, and in vivo self-renewal of multipotent mammalian neural crest stem cells. Cell 96: 737-749.

Morrison, S.J., Wandycz, A.M., Akashi, K., Globerson, A., and Weissman, I.L. 1996. The aging of hematopoietic stem cells. Nat. Med. 2: 1011-1016.

Morrison, S.J., Wandycz, A.M., Hemmati, H.D., Wright, D.E., and 
Weissman, I.L. 1997. Identification of a lineage of multipotent hematopoietic progenitors. Development 124: 1929-1939.

Mucenski, M.L., McLain, K., Kier, A.B., Swerdlow, S.H., Schreiner, C.M., Miller, T.A., Pietryga, D.W., Scott, W.J., and Potter, S.S. 1991. A functional c-myb gene is required for normal murine fetal hepatic hematopoiesis. Cell 65: 677-689.

Naughton, C.K., Jain, S., Strickland, A.M., Gupta, A., and Milbrandt, J. 2006. Glial cell-line derived neurotrophic factor-mediated RET signaling regulates spermatogonial stem cell fate. Biol. Reprod. 74: 314-321.

Nichols, J., Zevnik, B., Anastassiadis, K., Niwa, H., KleweNebenius, D., Chambers, I., Schöler, H., and Smith, A. 1998. Formation of pluripotent stem cells in the mammalian embryo depends on the POU transcription factor Oct4. Cell 95: 379-391.

Nishino, J., Kim, I., Chada, K., and Morrison, S.J. 2008. Hmga2 promotes neural stem cell self-renewal in young but not old mice by reducing $\mathrm{p} 16^{\text {Ink4a }}$ and $\mathrm{p} 19^{\text {Arf }}$ expression. Cell 3: 469 470.

Niwa, H., Burdon, T., Chambers, I., and Smith, A. 1998. Selfrenewal of pluripotent embryonic stem cells is mediated via activation of STAT3. Genes Dev. 12: 2048-2060.

Noctor, S.C., Martinez-Cerdeno, V., Ivic, L., and Kriegstein, A.R. 2004. Cortical neurons arise in symmetric and asymmetric division zones and migrate through specific phases. Nat. Neurosci. 7: 136-144.

Oatley, J.M. and Brinster, R.L. 2008. Regulation of spermatogonial stem cell self-renewal in mammals. Annu. Rev. Cell Dev. Biol. 24: 263-286.

Oguro, H., Iwama, A., Morita, Y., Kamijo, T., van Lohuizen, M., and Nakauchi, H. 2006. Differential impact of Ink4a and Arf on hematopoietic stem cells and their bone marrow microenvironment in Bmil-deficient mice. J. Exp. Med. 203: 22472253.

Ohta, H., Sawada, A., Kim, J.Y., Tokimasa, S., Nishiguchi, S., Humphries, R.K., Hara, J., and Takihara, Y. 2002. Polycomb group gene rae 28 is required for sustaining activity of hematopoietic stem cells. J. Exp. Med. 195: 759-770.

Orsted, D.D., Bojesen, S.E., Tybjaerg-Hansen, A., and Nordestgaard, B.G. 2007. Tumor suppressor p53 Arg72Pro polymorphism and longevity, cancer survival, and risk of cancer in the general population. J. Exp. Med. 204: 1295-1301.

Palmer, T.D., Takahashi, J., and Gage, F.H. 1997. The adult rat hippocampus contains primordial neural stem cells. Mol. Cell. Neurosci. 8: 389-404.

Pardal, R., Clarke, M.F., and Morrison, S.J. 2003. Applying the principles of stem-cell biology to cancer. Nat. Cancer Rev. 3: 895-902.

Pardal, R., Ortega-Saenz, P., Duran, R., and Lopez-Barneo, J. 2007. Glia-like stem cells sustain physiologic neurogenesis in the adult mammalian carotid body. Cell 131: 364-377.

Park, I.H., Zhao, R., West, J.A., Yabuuchi, A., Huo, H., Ince, T.A., Lerou, P.H., Lensch, M.W., and Daley, G.Q. 2008. Reprogramming of human somatic cells to pluripotency with defined factors. Nature 451: 141-146.

Park, I.-K., Qian, D., Kiel, M., Becker, M., Pihalja, M., Weissman, I.L., Morrison, S.J., and Clarke, M. 2003. Bmi-1 is required for the maintenance of adult self-renewing hematopoietic stem cells. Nature 423: 302-305.

Petersen, P.H., Zou, K., Krauss, S., and Zhong, W. 2004. Continuing role for mouse Numb and Numbl in maintaining progenitor cells during cortical neurogenesis. Nat. Neurosci. 7: 803-811.

Petersen, P.H., Zou, K., Hwang, J.K., Jan, Y.N., and Zhong, W. 2002. Progenitor cell maintenance requires numb and numblike during mouse neurogenesis. Nature 419: 929-934.

Pevny, L. and Placzek, M. 2005. SOX genes and neural progenitor identity. Curr. Opin. Neurobiol. 15: 7-13.

Puri, M.C. and Bernstein, A. 2003. Requirement for the TIE family of receptor tyrosine kinases in adult but not fetal hematopoiesis. Proc. Natl. Acad. Sci. 100: 12753-12758.

Qian, H., Buza-Vidas, N., Hyland, C.D., Jensen, C.T., Antonchuk, J., Mansson, R., Thoren, L.A., Ekblom, M., Alexander, W.S., and Jacobsen, S.E.W. 2007. Critical role of throm- bopoietin in maintaining adult quiescent hematopoietic stem cells. Cell Stem Cell 1: 671-684.

Rebel, V.I., Kung, A.L., Tanner, E.A., Yang, H., Bronson, R.T., and Livingston, D.M. 2002. Distinct roles for CREB-binding protein and p300 in hematopoietic stem cell self-renewal. Proc. Natl. Acad. Sci. 99: 14789-14794.

Reya, T., Morrison, S.J., Clarke, M.F., and Weissman, I.L. 2001. Stem cells, cancer, and cancer stem cells. Nature 414: 105-111.

Rodrigues, N.P., Janzen, V., Forkert, R., Dombkowski, D.M., Boyd, A.S., Orkin, S.H., Enver, T., Vyas, P., and Scadden, D.T. 2005. Haploinsufficiency of GATA-2 perturbs adult hematopoietic stem-cell homeostasis. Blood 106: 477-484.

Rossi, D.J., Bryder, D., Seita, J., Nussenzweig, A., Hoeijmakers, J., and Weissman, I.L. 2007. Deficiencies in DNA damage repair limit the function of haematopoietic stem cells with age. Nature 447: 725-729.

Rossi, D.J., Bryder, D., Zahn, J.M., Ahlenius, H., Sonu, R., Wagers, A.J., and Weissman, I.L. 2005. Cell intrinsic alterations underlie hematopoietic stem cell aging. Proc. Natl. Acad. Sci. 102: 9194-9199.

Roy, K., Kuznicki, K., Wu, Q., Sun, Z., Bock, D., Schutz, G., Vranich, N., and Monaghan, A.P. 2004. The Tlx gene regulates the timing of neurogenesis in the cortex. J. Neurosci. 24: 8333-8345.

Sanai, N., Tramontin, A.D., Quinones-Hinojosa, A., Barbaro, N.M., Gupta, N., Kunwar, S., Lawton, M.T., McDermott, M.W., Parsa, A.T., Manuel-Garcia Verdugo, J., Berger, M.S., and Alvarez-Buylla, A. 2004. Unique astrocyte ribbon in adult human brain contains neural stem cells but lacks chain migration. Nature 427: 740-744.

Sandberg, M.L., Sutton, S.E., Pletcher, M.T., Wiltshire, T., Tarantino, L.M., Hogenesch, J.B., and Cooke, M.P. 2005. cMyb and p300 regulate hematopoietic stem cell proliferation and differentiation. Dev. Cell 8: 153-166.

Sawamoto, K., Wichterle, H., Gonzalez-Perez, O., Cholfin, J.A., Yamada, M., Spassky, N., Murcia, N.S., Garcia-Verdugo, J.M., Marin, O., Rubenstein, J.L., et al. 2006. New neurons follow the flow of cerebrospinal fluid in the adult brain. Science 311: 629-632.

Saxena, R., Voight, B.F., Lyssenko, V., Burtt, N.P., de Bakker, P.I., Chen, H., Roix, J.J., Kathiresan, S., Hirschhorn, J.N., Daly, M.J., et al. 2007. Genome-wide association analysis identifies loci for type 2 diabetes and triglyceride levels. Science 316: 1331-1336.

Sharpless, N.E. and DePinho, R.A. 2007. How stem cells age and why this makes us grow old. Nat. Rev. Mol. Cell Biol. 8: 703-713.

Shen, Q., Zhong, W., Jan, Y.N., and Temple, S. 2002. Asymmetric Numb distribution is critical for asymmetric cell division of mouse cerebral cortical stem cells and neuroblasts. Development 129: 4843-4853.

Shen, Q., Wang, Y., Dimos, J.T., Fasano, C.A., Phoenix, T.N., Lemischka, I.R., Ivanova, N.B., Stifani, S., Morrisey, E.E., and Temple, S. 2006. The timing of cortical neurogenesis is encoded within lineages of individual progenitor cells. Nat. Neurosci. 9: 743-751.

Shi, Y., Chichung Lie, D., Taupin, P., Nakashima, K., Ray, J., Yu, R.T., Gage, F.H., and Evans, R.M. 2004. Expression and function of orphan nuclear receptor TLX in adult neural stem cells. Nature 427: 78-83.

Shors, T.J., Miesegaes, G., Beylin, A., Zhao, M., Rydel, T., and Gould, E. 2001. Neurogenesis in the adult is involved in the formation of trace memories. Nature 410: 372-376.

Sudo, K., Ema, H., Morita, Y., and Nakauchi, H. 2000. Ageassociated characteristics of murine hematopoietic stem cells. J. Exp. Med. 192: 1273-1280.

Suh, H., Consiglio, A., Ray, J., Sawai, T., D’Amour, K.A., and Gage, F.H. 2007. In vivo fate analysis reveals the multipotent and self-renewal capacities of Sox $2^{+}$neural stem cells in the adult hippocampus. Cell Stem Cell 1: 515-528.

Suzuki, A. and Saga, Y. 2008. Nanos2 suppresses meiosis and promotes male germ cell differentiation. Genes Dev. 22: $430-435$. 
Suzuki, H., Tsuda, M., Kiso, M., and Saga, Y. 2008. Nanos3 maintains the germ cell lineage in the mouse by suppressing both Bax-dependent and -independent apoptotic pathways. Dev. Biol. 318: 133-142.

Tadokoro, Y., Yomogida, K., Ohta, H., Tohda, A., and Nishimune, Y. 2002. Homeostatic regulation of germinal stem cell proliferation by the GDNF/FSH pathway. Mech. Dev. 113: 29-39.

Takahashi, K. and Yamanaka, S. 2006. Induction of pluripotent stem cells from mouse embryonic and adult fibroblast cultures by defined factors. Cell 126: 663-676.

Takahashi, K., Tanabe, K., Ohnuki, M., Narita, M., Ichisaka, T., Tomoda, K., and Yamanaka, S. 2007. Induction of pluripotent stem cells from adult human fibroblasts by defined factors. Cell 131: 861-872.

Temple, S. 2001. The development of neural stem cells. Nature 414: $112-117$.

Tothova, Z., Kollipara, R., Huntly, B.J., Lee, B.H., Castrillon, D.H., Cullen, D.E., McDowell, E.P., Lazo-Kallanian, S., Williams, I.R., Sears, C., et al. 2007. FoxOs are critical mediators of hematopoietic stem cell resistance to physiologic oxidative stress. Cell 128: 325-339.

Tsai, F.-Y., Keller, G., Kuo, F.C., Weiss, M., Chen, J., Rosenblatt, M., Alt, F.W., and Orkin, S.H. 1994. An early haematopoietic defect in mice lacking the transcription factor GATA-2. Nature 371: 221-226.

Tsuda, M., Sasaoka, Y., Kiso, M., Abe, K., Haraguchi, S., Kobayashi, S., and Saga, Y. 2003. Conserved role of nanos proteins in germ cell development. Science 301: 1239-1241.

Tyner, S.D., Venkatachalam, S., Choi, J., Jones, S., Ghebranious, N., Igelmann, H., Lu, X., Soron, G., Cooper, B., Brayton, C., et al. 2002. p53 mutant mice display early ageing-associated phenotypes. Nature 415: 45-53.

Valk-Lingbeek, M.E., Bruggeman, S.W., and van Lohuizen, M. 2004. Stem cells and cancer; the Polycomb connection. Cell 118: $409-418$.

van der Lugt, N.M., Domen, J., Linders, K., van Roon, M., Robanus-Maandag, E., te Riele, H., van der Valk, M., Deschamps, J., Sofroniew, M., van Lohuizen, M., et al. 1994. Posterior transformation, neurological abnormalities, and severe hematopoietic defects in mice with a targeted deletion of the bmi-1 proto-oncogene. Genes Dev. 8: 757-769.

van Praag, H., Schinder, A.F., Christie, B.R., Toni, N., Palmer, T.D., and Gage, F.H. 2002. Functional neurogenesis in the adult hippocampus. Nature 415: 1030-1034.

Wang, J., Rao, S., Chu, J., Shen, X., Levasseur, D.N., Theunissen, T.W., and Orkin, S.H. 2006. A protein interaction network for pluripotency of embryonic stem cells. Nature 444: 364-368.

Ware, C.B., Horowitz, M.C., Renshaw, B.R., Hunt, J.S., Liggitt, D., Koblar, S.A., Gliniak, B.C., McKenna, H.J., Papayannopoulou, T., Thoma, B., et al. 1995. Targeted disruption of the low-affinity leukemia inhibitory factor receptor gene causes placental, skeletal, neural and metabolic defects and results in perinatal death. Development 121: 1283-1299.

Wellcome Trust Case Control Consortium. 2007. Genome-wide association study of 14,000 cases of seven common diseases and 3,000 shared controls. Nature 447: 661-678.

Yamanaka, Y., Ralston, A., Stephenson, R.O., and Rossant, J. 2006. Cell and molecular regulation of the mouse blastocyst. Dev. Dyn. 235: 2301-2314.

Yilmaz, O.H., Kiel, M.J., and Morrison, S.J. 2006. SLAM family markers are conserved among hematopoietic stem cells from old and reconstituted mice and markedly increase their purity. Blood 107: 924-930.

Ying, Q.L., Nichols, J., Chambers, I., and Smith, A. 2003. BMP induction of Id proteins suppresses differentiation and sustains embryonic stem cell self-renewal in collaboration with STAT3. Cell 115: 281-292.

Ying, Q.L., Wray, J., Nichols, J., Batlle-Morera, L., Doble, B., Woodgett, J., Cohen, P., and Smith, A. 2008. The ground state of embryonic stem cell self-renewal. Nature 453: 519-523.

Yoshida, K., Taga, T., Saito, M., Suematsu, S., Kumanogoh, A., Tanaka, T., Fujiwara, H., Hirata, M., Yamagami, T., Nakahata, T., et al. 1996. Targeted disruption of gp130, a common signal transducer for the interleukin 6 family of cytokines, leads to myocardial and hematological disorders. Proc. Natl. Acad. Sci. 93: 407-411.

Yoshihara, H., Arai, F., Hosokawa, K., Hagiwara, T., Takubo, K., Nakamura, Y., Gomei, Y., Iwasaki, H., Matsuoka, S., Miyamoto, K., et al. 2007. Thrombopoietin/MPL signaling regulates hematopoietic stem cell quiescence and interaction with in the osteoblastic niche. Cell Stem Cell 1: 685-697.

Yu, F., Yao, H., Zhu, P., Zhang, X., Pan, Q., Gong, C., Huang, Y., Hu, X., Su, F., Lieberman, J., and Song, E. 2007a. let-7 regulates self renewal and tumorigenicity of breast cancer cells. Cell 131: 1109-1123.

Yu, J., Vodyanik, M.A., Smuga-Otto, K., Antosiewicz-Bourget, J., Frane, J.L., Tian, S., Nie, J., Jonsdottir, G.A., Ruotti, V., Stewart, R., Slukvin, I.I., and Thomson, J.A. 2007b. Induced pluripotent stem cell lines derived from human somatic cells. Science 318: 1917-1920.

Zeggini, E., Weedon, M.N., Lindgren, C.M., Frayling, T.M., Elliott, K.S., Lango, H., Timpson, N.J., Perry, J.R., Rayner, N.W., Freathy, R.M., et al. 2007. Replication of genome-wide association signals in UK samples reveals risk loci for type 2 diabetes. Science 316: 1336-1341.

Zhang, C.L., Zou, Y., He, W., Gage, F.H., and Evans, R.M. 2008. A role for adult TLX-positive neural stem cells in learning and behaviour. Nature 451: 1004-1007.

Zindy, F., Quelle, D.E., Roussel, M.F., and Sherr, C.J. 1997. Expression of the p16 ${ }^{\mathrm{INK} 4 \mathrm{a}}$ tumor suppressor versus other INK4 family members during mouse development and aging. Oncogene 15: 203-211. 


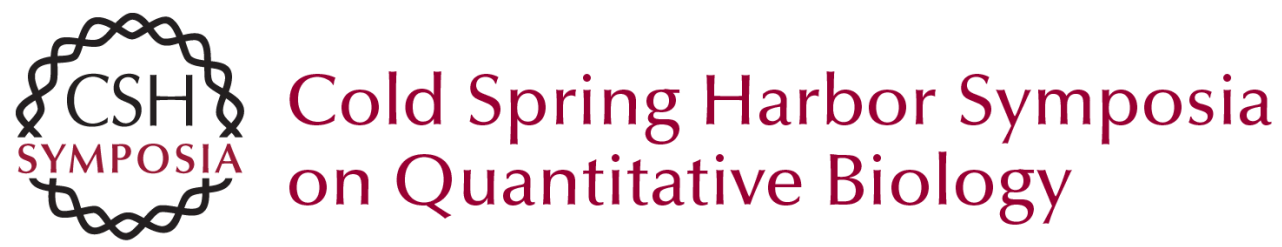

\section{Stem Cells Use Distinct Self-renewal Programs at Different Ages}

B.P. Levi and S.J. Morrison

Cold Spring Harb Symp Quant Biol 2008 73: 539-553 originally published online January 15, 2009

Access the most recent version at doi:10.1101/sqb.2008.73.049

References This article cites 171 articles, 62 of which can be accessed free at: http://symposium.cshlp.org/content/73/539.full.html\#ref-list-1

License

Email Alerting Receive free email alerts when new articles cite this article - sign up in the box at the Service top right corner of the article or click here.

To subscribe to Cold Spring Harbor Symposia on Quantitative Biology go to:

http://symposium.cshlp.org/subscriptions 